\title{
Transferring Alberta's Gas Flaring REDUCtion REgULATORY FRAMEWORK TO NIGERIA: POTENTIALS AND LIMITATIONS
}

\author{
IBIRONKE T. ODUMOSU
}

The article reniews the Albertan and Nigerian gas flaring regulatony frameworks. examimes their differences, and attempss on determine the extem to which cortoin aspects of the Alberian framenork can (not) be adopted in Nigeria. In this regard. the author also offers a brief review of various legal rransplam theories and a backyround of regulation in both jurisdictions. The author ends by offering suggestions as to what concepts and principles man (not) be viably. transferred.
Cet arficle eramine les differences entre les struchures reglememaires de l'Alborta et dil Nigcria relatives an brilage de gaz, el essaic de deverminer la mesure dans laquelle certains aspects de la strmoture alberfuine peutem (ne petnent pas) ètre adoptes an Nigiria. i cet egard. Iauteur donne aussi un href apercu des diverses theories de transfert juridique et le contexte de la reglementation dans les deux juridictions. L auteur termine en donnant des suggestions quam aur concepts et principes pouvant (n' potwant pas) eitre transfereis avec succè.s.

\section{TABLE OF CONTENTS}

I. JNTRODUCTION ............................ 863

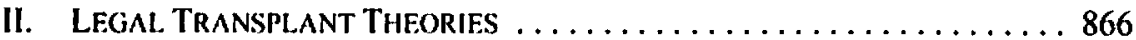

A. TIIE SCHOOLS Of THOUGHT .................. 868

B. Determiningi Success in Legal Transplants $\ldots \ldots \ldots \ldots . . .871$

III. The Albertan AND Nigerian OII. AND Gas Systems $\ldots \ldots \ldots \ldots 872$

A. BACKGROUND TO THE REGUI.ATION OF

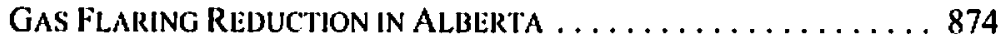

B. BACKGiROUND TO THIE REGULLATION OF

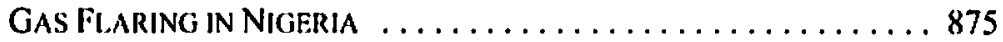

C. Til: InSTITUTIONAL MECHANISMS $\ldots \ldots \ldots \ldots \ldots \ldots \ldots \ldots 77$

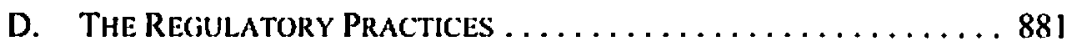

IV. SYNTHESIS AND SUGgestions For TRANSFER $\ldots \ldots \ldots \ldots \ldots \ldots . \ldots 93$

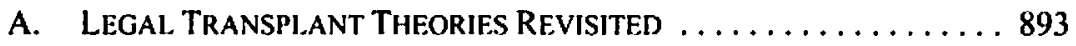

B. OutLINEd DifFerfances $\ldots \ldots \ldots \ldots \ldots \ldots \ldots \ldots \ldots . \ldots \ldots 4$

C. TRANSFLRABLL CONCEPTS AND PRINCIPLES $\ldots \ldots \ldots \ldots \ldots . \ldots 96$

V. CONCLUSION ............................... 901

\section{INTRODUCtION}

Since the turn of the 20th century, oil and gas production has been a source of development and significant revenue for many countries. The Canadian province of Alberta and the country of Nigeria are jurisdictions where oil and gas production has taken place on

Doctoral Candidale, Faculty of Law, University of British Columbia. Professor Nigel Bankess and Janet Kecping provided tremendously helpful comments on tarlier drafts, which 1 especially appreciate. The research for the article was conducted while I was studying for the Master of Latus (LL.M.) degrec at the University of Calgary. I thank Professors Nigel Bankes, Alastair Lucas, Jonnette Watson Ilamilton. and Michael Wenig for a series of helpful discussions and an inspiring learning environment. The project could not have been completed without the generosity of the Canadian Institute of Resources Law, the MeDermids, and the Faculties of Law and Ciraduate Studies at the University of Calgary. 
a large scale in the past century. Oil and gas production, like most natural resource exploitation, involves both positive and negative impacts; gas flaring is one of the impacts that has huge negative consequences on many spheres of society.

Gas flaring is not a petroleum industry activity that is peculiar to any particular oil and gas-producing jurisdiction and has attracted international attention through the World Bank's Global Gas Flaring Reduction (GGFR) Partnership. ${ }^{2}$ Oil-producing companies flare and vent about 110 billion cubic meters $\left(\mathrm{bm}^{3}\right)$ of associated gas around the world each year ${ }^{3}-\mathrm{a}$ significant waste of a valuable non-renewable resource, which is also one of the cleanest sources of energy. Flaring is also a serious environmental concern because of its contribution to local environmental degradation and climate change. ${ }^{4}$ In Nigeria, the gas flaring situation is extreme. Nigeria is an associated gas province; production of oil entails production of natural gas." The country has the highest gas flaring rate among the member states of the Organization of the Petroleum Exporting Countries (OPEC), flaring more than half of its produced natural gas.. By 2002, Nigeria's flared gas alone accounted for about 20 percent of the global total ${ }^{7}$ and some flares in Nigeria have burnt non-stop for over 40 years. ${ }^{8}$

1 Gas flaring is the buming of natural gas at the wellhead. Associated natural gas - gas discovered in crude oil. coal, or bitumen production - is usually the subject of flaring. Flaring can occur during well testing, mainlenance operations, emergencies, and other production operations. However, most of the tharing in the petroleum industry occurs as a form of routine disposal of flammable gases that are either unusable or unceonomic to recover.

: Sec "Oil, Gas. Mining \& Chemicals," online: The World Bank <www.worldbank.org/ogme/global_ gas.hitm:-

3 The Workl Bank estimates that enough gas is llared and vented every year to provide the combined annual natural gas constumption of Ciermany and France. See World Bank, "Regulation of Associated (ias l:laring and Venting: A Global Overview and Lessons from Intemational Experience," Global Gas Filaring Keduction - Report No. 3 (Washington: World Bank, 2004) at 1. This article focuses on gas flaring only and not on venting.

1 Many countries including Canada and Nigeria have ratified the 1992 United Nations Framework Comention on Climate Change, 9 May 1992, 1771 U.N.T.S. 107, 31 1.L.M. 849 and the 1997 Kyoto Protecot wo the United Nations Framework Comvention on Climate Change, 11 December 1997, 37 1.L.M. 32.

See Jackson Giaius-Ohascki, "Welcome Address" (Paper presented to the First Annual Workshop of the Nigerian (ias Association, Abuja, Nigeria, 1 November 1999) [unpublished]. On average, about 1000 standard cubic fect (sct) of gas is produced with every barrel of oil in Nigeria. See Basil Omiyi, "Shell Nigeria Corporate Strategy for linding Gas Flaring" (Paper presented to the Seminar on Gas Flaring and Poverty Alleviation, Oslo, Nonway, 18 June 2001) at 2, online: Climate Justice <www.climatelaw.org/ gas.flaring/report/section4/doc4.I.pdis.

" "Nalural Gas," online: Nigerian Oil-Gas Online<www.nigerianoil-gas.com/naluralgas/index.htm>. Note that there are conflicling statistics on the percentage of gas flared in Nigeria annually but, whatever the actual tigures, there is significant gas flaring in Nigeria. In 2004, the World Bank confirmed a 75 percent annual gas flaring rate. Sec Energy Information Association (EIA). Counmy Analysis Briefs: Nigeria (March 2006), online: F.IA <www.cia.doc.gov/emeu/cabs/Nigeria/pdf.pdi> [EIA 2005].

World Bank, "Report on Consultations with Stakeholders," Global Gas Flaring Reduction - Report No. I (Washington: World Bank. 2004) [GGFR No. 1].

- Fighty-five percent of all fared gas in Nigeria is associaled gas. Sec Manby Bronwen. The Price of Oil: Corporalc Re'sponsibility and Human Rights Violalions in Nigeria's Oil Producing Communities (New York: Iluman Rights Watch, 1999) at 72; Joint UNDP/World Bank Energy Sector Management Assistance Programme (ESMAP), Taxation and State Participation in Nigeria's Oil and Gas Sector (Washington: The Inicmational Bank for Reconstruction and Development/THE WORLDBANK, 2004) at 73. online: ESMAP < WWw.esmap.org/filez/pubs/05704NigeriaTaxationMcPherson.pdf>. 
A World Bank GGFR study jdentifies three main barricrs to natural gas conservation: a lack of an effective regulatory framework; a lack of ready local and international markets; and financing constraints for gas flaring reduction projects." $A l l$ of these factors are present in the Nigerian natural gas sector. Apart from the practical and economic problems of unavailable markets, claims of lack of necessary infrastructure, and financial constraints, legal problems include ineffective legislation, regulation, and implementation of laws and policies. All of these concerns are discussed in this article.

This article advocates reform of the legislative and regulatory framework on the one hand, and the restructuring of the regulatory institutions responsible for ensuring gas flaring reduction in Nigeria on the other, in order to establish an effective regulatory regime for gas flaring reduction, and possibly its elimination, while recognizing the limitations caused by insufficient markets. The article examines the viability of adopting the Alberta gas flaring reduction framework as a basis for a reform of the Nigerian regulatory regime. ${ }^{10}$ The examination of the transferability of the Alberta framework to Nigeria stems from several factors. First, the World Bank endorsed the Alberta Energy and Utilities Board (AEUB), the regulator of Alberta's oil and gas industry, as a global model for reducing natural gas flaring. The AEUB has been sharing its regulatory approaches with other jurisdictions including Nigeria." The AEUB has achieved an "all time record" in gas conservation and seems to have significantly curbed gas flaring in Alberta." Second, there are several similarities between Alberta and Nigeria: both are common law jurisdictions with large oil and gas reserves and have both had major gas flaring at one time or the other. Third, Alberta's regulatory framework for oil and gas conservation was developed specifically in response to gas flaring and has proven practical applications.

Although the Alberta framework has been successful in Alberta, one cannot merely assume that Nigeria can adopt this regime. Thus, I examine the transferability of Alberta's gas flaring reduction framework to Nigeria against the backdrop of the different strands of legal transplant theory. The engagement with legal transplant theory and legal transferability in this article is limited to the transfer of gas flaring reduction mechanisms and does not extend to law and legal institutions generally. This is in recognition of the fact that law and legal institutions, especially those that affect the established cultural patterns of a nation, do not lend themselves easily to acceptance when transfierred. Essentially, Alberta's gas flaring reduction regime, like most of its oil and gas regulatory mechanisms, is based on two principal regulatory approaches: (1) the independent regulatory agency method of administrative regulation and (2) the adoption of well-defined and well-developed oil and gas conservation practices. This article analyzes the transferability of the regulatory choices that

- GGFR No. 1, supra note 7.

10 The purpose of this article is not to critique the Alberta gas flaring reduction mechanism, as that is an entirely different project. Rather, it secks to answer one question - whether the Alberta gas flaring reduction framework, as it currently stands, is transferable to Nigeria and. if so, what possible positive outcomes may arise.

"AEUB, "EUB to share flaring success with developing eountries" Across the Boctrd (October 2003) at 3, online: AEUB <www.cub.gov.ab.ca/bbs/products/newsletter/pdf/ath_october_2003.pdi>.

12 There is, however, a lot of public concern regarding. and opposition to the percentage of gas especially sour gas - that is still flared in the province. Sec, e.g., Jennifer Huang. "Natural Gas Burns. and Communities Cry Foul III: Alberta" Nensdesk.org (12 November 2002) online: Newsdesk.org Independent Arts and Media <www,artsandmedia.neV/cgi-bin/dc/newsdesk/2002/1 1/12_flaring_3>. 
are derived from these two principal approaches. Even though these regulatory approaches are not constitutional in nature, they affect local populations and are sometimes dictated by the jurisdiction's legal culture and socio-economic and political considerations. As a result, the article accentuates the differences in Alberta and Nigeria that affect the gas flaring regime. The article also provides an analysis of Alberta's gas flaring regulatory mechanisms, Nigeria's gas flaring framework, and a synthesis of both systems that culminates in suggestions for the reform of the Nigerian system.

My discussion of the viability of adopting Alberta's legislative and regulatory framework for gas flaring reduction in an oil and gas-rich developing country like Nigeria proceeds in stages. First, I set out the theoretical arguments on legal transplants. Scholarly perspectives on legal transplants explain the transferability of legal rules and concepts and provide an avenue for a better understanding of the movement of laws across borders. Second, I provide a concise historical account of the development of gas flaring regulation in Alberta, in order to determine the factors that worked in favour of, or against, the province in developing an effective regulatory mechanism for gas flaring reduction. Third, I briefly outline relevant Nigerian legislative and regulatory provisions, as well as obstacles encountered in gas flaring regulation. The legal transplant theories examined provide the basis for a comparative analysis of the approaches to gas flaring reduction in Nigeria and Alberta. Based on these, I will provide a synthesis and outline an effective gas flaring reduction regime for Nigeria. This article adopts a pragmatic approach. The suggestions for reform outlined in Part IV are practical, result-oriented, and are geared towards affecting policy.

\section{Legal Transplant Theories}

[The h] istory of a system of law is largely a history of borrowings of legal materials from other legal systems and of assimilation of materials lrom outside of the law. ${ }^{13}$

The transfer of legal rules and principles - legal transplants - is a practice that most jurisdictions have encountered and are familiar with to varying degrees. Professor Alan Watson describes a legal transplant as "the moving of a rule or a system of law from one country to another, or from one people to another." ${ }^{14}$ Therefore, legal transplantation is the transfer of established laws and legal institutions from one jurisdiction to another. Legal transplants occur for several reasons, including imposition, ${ }^{15}$ chance, ${ }^{16}$ and prestige. ${ }^{17}$ While

1 Roscoe Pound, quoted in Alan Watson, Legal Transplants: An Approach to Comparative Law (Charloltesville, Va.: University Press of Virgina, 1974) at 22 [Watson, Legal Transplants].

it Watson, Legal Transplants, ibial. at 21.

1s The literature on imposition is wide and outside the purview of this article. Apart from imposition (for example, the reception of Linglish common law in Nigeria, and in most of Canada). a legal transplant might occur through imposed or voluntary reception. It is arguable that the activities of the World Bank in pushing for gas flaring reduction regulatory models and enacting a framework from various international models may amount to imposed reception because of the role the World Bank plays in developing economies. For general information on modes of reception, see Jonathan M. Miller. "A Typology of L.egal Trunsplants: Using Sociology, Legal History and Argentine Examples to Explain the Transplunt Process" (2003) 51 Am. J. Comp. L. 839 and John C. Reitz, "Systems Mixing and in Transition: Import and Expon of Legal Models" in John W. Bridge, ed., Comparative Law Facing the 2/si Century (London: The Uniled Kingdom National Committee of Comparative Law, 2001) 58 at 79. 80. For comments on World Bank activities on import and export of law, see Yves Dezalay \& Bryant 
imposition occurs within colonial and neo-colonial contexts, some commentators suggest that legal transplants could occur serendipitously where the policy-makers of a jurisdiction are trained in another and, inadvertently or not, import the legal culture of the jurisdiction of their training. However, some could read this as an instance of colonialism or its variations. According to the prestige argument, there is usually a desire to appropriate the work of others because of the latter's quality. ${ }^{18}$ The economic afficiency rationale is similar to the prestige argument. Put succinctly, it is "whatever legal arrangement 'they' have that 'we' wish to have because by having it they are better off."1" According to the efliciency argument, borrowing is convenient, ${ }^{21}$ expedient, ${ }^{21}$ and of practical utility. ${ }^{22}$ Professor Friedman premises his efficiency argument on the fact that legal transplants are offshoots of modemization and industrialization phenomena that transform societies and create new needs and new problems to be solved. To solve these problems or meet these needs, "countries adapt, beg, borrow, or steal law from places that have faced the problems earlier, or came up with an earlier response." ${ }^{23}$ The legal transplant considered in this article is premised on the efficiency argument as it seems expedient to borrow from a jurisdiction that has devised means of solving a problem. However, extreme caution should be taken in examining the differences between the jurisdictions that might not make a total transfer feasible. As such, it might be more apt to consider this endeavour as leaming from a jurisdiction with a longer history of gas flaring and solving the problem. This is a case of adapting the adaptable from this jurisdiction, while leaving those that do not fit into the recipient's legal culture in the realm of information.

Legal transplants vary in form and size..$^{24} \mathrm{~A}$ transplant could involve the transfer of single rules, a portion of the law, ${ }^{25}$ or an entire legal system as in the case of Nigeria and other British colonies' reception of the common law. Based on the complexity and varying types of legal transplants, Professor Foster argues that any search for a "Grand Transplant Theory" is a "wild goose chase." He states that we have to be content with hypotheses at different

Garth. "The Import and Export of Law and Legal Institutions: International Stralcgies in National Palace Wars" in David Nelken \& Johannes Feest, eds., Adapting Legal Culhures (Oxford: Ilan Publishing. $2001) 241$.

Alan Watson, "Aspects of Receplion of I.aw" (1996) 44 Am. J. Comp. L. 335 at 339 [Watson, "Reception"]: Gianmaria Ajani, “By Chance and Prestige: Legal Transplants in Russia and Eastern Europe" (1995) 43 Am. J. Comp. L. 93.

Ugo Mattei, "Efriciency in Legal Transplants: $\Lambda$ n Essily in Comparative Law and Fecononics" ( 994$)$ 14 Int'l Rev. L. \& Econ. 3.

Rodolfo Sacco. "Legal Formants: A Dynamic Approach to Comparative Law (Installment Il of II)" (1991) 39 Am. J. Comp. L. 343. For more on prestige sec, Ajani, supra nole 16 at 93. Mattci, supra note 17 at 19.

Pierre Legrand. "What "Legal Transplants"?" in Nelken \& Feest, supra note 15, 55 at 64 [Legrand, "What Legal Transplants?"].

Lawrence Friedman, "Some Comments on Colterrell and Legal Transplants" in Nelken \& Feest, ibid., 93 at 93.

Watson, "Reception." supra note 16 at 335.

Friedman, supvo nole 21 at 94.

Watson, "Reception," supra note 16 at 335.

Lorraine M. McDonough, "The Translerability of Labor Law: Can an American Transplant Take Root in British Soil?" (1992) 13 Comp. Lab. L. J. 504.

Nicholas Foster, "Transmigration and Transferability of Commercial Law in a Globalized World" in Andrew Harding \& Esin Orücil, eds., Compararive Law in the 2/st Century (The l lague: Kluwer Law International, 2002) 55 at 71 . 
levels of generality. The theories of legal transplant can be divided into three groups, each approaching the subject from different view points, which I discuss next. I name each variation after its principal proponent.

\section{A. THE SChOOLS OF THOUGHT}

It is possible to locate strands of legal transplant theory on a continuum of legal transferability, starting from the autonomy of law position, to the perspectives of legal sociologists, and finally to the position of those commentators that subscribe to the view that law is inherently not transferable. However, the positions of legal transplant theorists discussed in this section are by no means ordered chronologically. They only reflect the perspectives of scholars on legal transferability and the degrees of such transfer.

\section{ALAN WATSON'S THEORY}

Professor Watson premises his legal transplant theory on the position that law is autonomous. He states that "successful borrowing could be made from a very different legal system, even from one at a much higher level of development and of a different political complexion." ${ }^{27}$ For him, a law reformer should look for ideas, which could be transferred to his country from a foreign system. Watson draws his example from the "massive transfusion" of Roman law to Western Europe and states that one cannot simply accept Montesquieu's claim that legal transplants constitute "un grand hazard." 28 Watson's argument is that the reception of laws at different times in history shows that a legal transplant could still occur and be successful even if the social, political, economic, and geographical conditions of the donor and recipient jurisdictions were different.

Watson, however, concedes that where the donor's law is inimical to the political, social, or economic circumstances of the recipient state, the possibility of a legal transplant would be greatly diminished..$^{29} \mathrm{However}$, he disagrees with Otto Kahn-Freund's principal thesis that the degree to which legal rules can be borrowed depends on their linkage with the foreign power structure, and further, that knowledge of the foreign law and its political context is necessary for legal transplants. ${ }^{30}$

For Watson, legal transplants are a major tool for law reform ${ }^{31}$ and legal change. ${ }^{32} \mathrm{He}$ states that at least in the Western world, legal transplants have been the major feature of legal change for about a thousand years. ${ }^{31}$ Commenting on his view of what William Ewald calls the "mirror theory of law," ${ }^{34}$ Watson states that law exists in society and for society's needs.

\footnotetext{
: $\quad$ Alan Watson. "Legal Transplants and Law Reform" (1976) 92 Law Q. Rev. 79 at 79.

$\therefore \quad$ Ibid. at 80 .

$\therefore$ Ibid. at 81 .

ti) Ibid. al 82 .

"Watson, legal Transplants, supra nole 13 at 17.

3: Alan Watson, "Comparative Law and Legal Change" (1978) 37 Camb. L.J. 313 [Watson, "Legal Change"]. See also, Watson, "Reception," sipra note 16 at 335.

Watson, "Legal Change," ibid. at 314.

William Ewald, "Comparative Jurisprudence (II): The Logic of Legal Transplants" (1995) 43 Am. J. Comp. L. 489. The mirror theory of law states that law rellects some fonces, which are extemal to it. It is an argument against the autonomy of law.
} 
The perennial question, as he calls it, is whether legal rules reflect a society's desires, needs, and aspirations. ${ }^{35}$ The common answer is of course positive. But Watson argues to the contrary. He states that in spite of the differences between jurisdictions, "the two most startling, and at the same time most obvious, characteristics of legal rules are the apparent ease with which they can be transplanted from one system or society to another, and their capacity for long life." ${ }^{36}$

Watson bases his transplant theory on three premises. The first is that law generally possesses a life and vitality of its own. Second, legal rules operate at the level of ideas. ${ }^{37}$ The third premise is that the best approach to understanding and knowing the law, its functions, and the demands on it, is through the history of the rules, their origin, their development, and their transformation in different systems. ${ }^{38}$ For Watson, there is no inherent relationship between any legal system or rules and the society in which they operate. Watson's theory suggests that it is possible to transfer Alberta's regulatory framework for gas flaring reduction to Nigeria, irrespective of any differences that may exist between the jurisdictions. His is a legal positivist perspective on legal transplants. His work has triggered a flood of replies and debate by legal sociologists who contend that there is a necessary connection between law and society.

\section{OTTO KAHN-FREUND'S THEORY}

This sub-section discusses the views of the scholars who adopt the mirror theory of law. For this group of writers, there is a necessary connection between law, legal change, and legal transplants on the one hand, and socio-cultural and political factors on the other. Like Montesquieu, many of these scholars take the view that legal transplants constitute "un grand hazard." 39

Professor Kahn-Freund bases his propositions on the premise that there are degrees of transferability and states that it is necessary to inquire whether there is any chance that the new law will adjust to its new environment because there are risks of rejection. ${ }^{40} \mathrm{He}$ agrees with Montesquieu that factors external to law, especially politics, affect the transferability of law across jurisdictions. The question according to Kahn-Freund is "how far does this rule or institution owe its existence or its continued existence to a distribution of power in a foreign country which we do not share?"*41 For the purpose of this article, I rephrase the question as follows: how far do the gas flaring reduction regulations in Alberta owe their existence or continued existence to a distribution of power and socio-economic factors, which Nigeria does not share? This article engages this question in its discussion of Alberta and Nigeria's gas flaring reduction mechanisms, the factors that shape those mechanisms, and the socio-political and economic differences between the jurisdictions.

Watson, "Legal Change," supra note 32 at 313.

lbid.

See Steven 3. Heim. "Predieting Legal Transplants: The Case of Servitudes in the Russian Federation" (1996) 6 Transnat'I Law \& Contemp. Probs. 187 at 193.

Watson. "Legal Change," supra note 32 at 316.

Supra note 26 at 58. See also MeDonough, supra note 25 at 504.

O. Kahn-Freund, "On Uses and Misuses of Comparative Law" (1974) 37 Mod. L. Rev. 1 at 6.

Ibid. at 12. 
On degrees of transferability, Kahn-Freund illustrates with two examples - the transplant of a kidney, which he refers to as organic transplant, and the transplant of a carburetor from one car to another, which is a mechanical transplant. The former is more difficult than the latter and, in the former, it makes sense to ask whether the body will reject the transplanted kidney. To ask this question of the carburetor is "ridiculous." constitutional, legislative, administrative, or judicial institutions and perform rule making, decision making, and policy-making functions are closest to the organic end of the continuum and are the ones most resistant to transplantation. ${ }^{43}$ Although Kahn-Freund argues that it cannot be taken for granted that rules of institutions are transplantable, he concedes that the obstacles to transplantation are formidable. ${ }^{44}$ For him, knowledge of the foreign law, its social context and, more importantly, its political context is necessary. ${ }^{45}$

The thesis of this second school of thought is that law cannot be divorced from society and societal influences. The society and the culture of a people contribute to the manner in which they perceive their law and legal institutions and, therefore, affect legal transplants. Transplanted law does not always fit into society; and not only does law have a social context, it also makes its own context. ${ }^{\text {th }}$ For this group of theorists, law reflects the "spirit" and the "common consciousness" of the people. ${ }^{47}$ The basic question (which this article addresses) seems to be this: Do the gas flaring reduction regulations and regulatory institutions in Alberta reflect the spirit and the common consciousness of Albertans so that it is difficult to transplant them elsewhere or even make their transplant impossible?

\section{Pierre Legrand's Theory}

Pierre Legrand's arguments differ from the two legal transplant theories discussed earlier. ${ }^{48}$ Legrand argues that legal transplants are a virtual impossibility. He states that a legal rule is "necessarily an incorporative cultural form." ${ }^{\text {"49 }}$ For him, law and legal institutions cannot be transferred from one jurisdiction to the other. If anything is displaced from one jurisdiction to another, it is literally a "meaningless form of words." ${ }^{50}$ The words cannot have the same significance they had in the jurisdiction from which the law was borrowed because meaning is not subject to international negotiations; it cannot be transplanted across

Ihid. at 6.

Ibid. at 17.

Jbid. at 20, 27.

Jbid. at 20. See also Roger Cotterrell, "Is there a Logic of Legal Transplants?" in Nelken \& Feest, supra note 15,71 at 90 .

David Nelken, "Comparatists and transferability" in Pierre Legrand \& Roderick Munday, eds., Comparative Legal Studies: Traditions and Transifions (Cambridge: Cambridge University Press, 2003) 437 at $451-52$ [Nelken. "Comparatists and transferability"].

This echoes the words of the 19 th ecntury German scholar, Friedrich Karl von Savigny. For a quotation of von Savigny's work, ste Watson, l.egal Trumsplants, supra note 13 at 21.

Pierre Legrand, "The Impossibility of 'Legal Transplants"” (1997) 4 M.J.E.C.L. 111 [Legrand, "Impossibility"]; Legrand, "What Legal Transplants?," supra note 20 at 55.

Legrand, "What Legal Transplants?," ibid. at 59.

lbid. at 63. 
jurisdictions. Legrand states that as the law crosses boundaries, "the original rule necessarily undergoes a change that affects it qua rule." ${ }^{\text {"I }}$

Nelken criticizes Legrand for placing exaggerated emphasis on differences rather than on similarities. ${ }^{52} \mathrm{He}$ argues that Legrand's view is, although incontrovertible, unhelpful when taken at it strongest because no one attempts to use laws and legal institutions to produce identical meanings and effects in different cultures as this is impossible. He adds that this is not what even Watson, who coined the term legal transplant, intended. Essentially, the arguments seem to turn on the meaning each author attaches to the term "legal transplant." However, it is undeniable that transfers have always taken place, are taking place, and will take place. ${ }^{33}$ In the light of criticisms, Legrand has modified his claims but continues to insist on the impossibility of comprehending others as they do themselves. ${ }^{5.4}$

Though oil and gas conservation regulations are technical and may seem to be devoid of any particular socio-cultural meaning, the effects of the same regulations within the economy and politics of different jurisdictions might differ. This is especially true when considering the realities of the differences between the needs and capabilities of developed and developing countries. Also, the institutional structure of the AFUB seems culture-specific, and it might have achieved its level of regulatory success because of historical factors and a distribution of power that may not necessarily be present in Nigeria. As a result, in Parts III and IV of this article, I discuss the gas flaring reduction mechanisms of both jurisdictions with deference to the effects of these different factors on the jurisdictions.

\section{B. Deternining Success in Legal Transpl.ants}

The meaning of both success and failure in legal transplants vary. Is a legal transplant successful when it is appropriately adapted to fit the recipient system? Or is success attained when the recipient jurisdiction gives it the same meaning it had in the donor jurisdiction? Is it successful when the results achieved in the donor system are also achieved in the recipient system, whether or not the transplanted law acquires the same meaning? These are several questions that academics and policy-makers need to consider with regard to the viability of legal transplants. Generally, failure of a legal transplant can occur where the recipient state totally rejects the transplanted law..$^{55}$ Scholars measure success in transplants by criteria that transcend a general consideration of the total rejection of transplanted law. The first measure is the complete absorption of the transplanted law into the legal and political culture that

Ibid. Like Legrand, the Seidmans also developed a "law of inon-transferability of law." Sec Ann Scidman \& Robert B. Scidman, State and lan in the Development Process: Problem-Solving and lnstitutional Change in the Third World (New York: St. Martin's Press, 1994). They refer (at 44) to "the more general question of why no governmemt can expect to develop by copying some other country's supposedly "successful" model." Sece also Ann Scidman \& Robert B. Scidman, "Dralting Legislation for Development: Lessons from a Chinese Project" (19)(6) 44 Am. J. Comp. L. I at 40. Nelken, "Comparutists and transferability." supros note 46 at 442.

Ibid. at 443.

\$4 Pierre Legrand, "The same and the different" in Legrand \& Munday, sitpra nole 46, 240.

35 For example, altempts to transfer American labour law to Britain were rejected and the law had to be repealed. See McDonough, supra note 25 at 518. 
imported it. ${ }^{36}$ The second measure depends on the recipient jurisdiction forgetting the origins of the transfer. As such, it is logical that commentators arguc that the more similar two societies are the more likely it is that a transfer will succeed. ${ }^{57}$

Generally, the success of a legal transplant depends on how well the transplanted law is able to adapt to its new environment. Success also depends on the intended purpose of the transplant. If the transplanted law serves this purpose it can be regarded as successful. Alberta adopted its oil and gas conservation laws from the United States, ${ }^{5 K}$ but it has modified these principles over the last century and developed a model that suits and serves its own purposes. In the Alberta-Nigeria situation, success will be attributable if there is, in fact, a transplant of Alberta's framework for gas flaring reduction to Nigeria and gas flaring is permanently reduced as a result.

The oil and gas industries in Nigeria and Alberta operate in different socio-economic and political systems, but there is a certain degree of comparability between the industries, the regulatory framework, and the institutional structures that allows the possibility of some beneficial transfer. Even if the regulatory framework for gas flaring reductions employed in Alberta cannot be transferred to Nigeria, the latter can learn from the experience of the former - the problems that have arisen and the mechanisms applied in problem solving and this would provide possible solutions in Nigeria. Essentially, a study of Alberta's gas flaring reduction regulatory framework with a view to possible application in Nigeria cannot be an exercise in futility for, if nothing else, the latter would have acquired added information on mechanisms that could work within its system and those that simply cannot be incorporated.

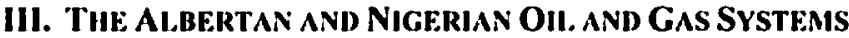

Similarities in the donor and recipient jurisdictions are a major source of strength for legal transplants, as significant divergence in values, beliefs, and structures diminish the possibilities of successful legal transplants. As a result, this Part aims to provide an outline of Alberta and Nigeria's gas flaring reduction frameworks in order to provide sufficient background information necessary for analyzing the potentials and limitations of a transfer of gas flaring reduction mechanisms. I adopt a historical approach in discussing the components of Alberta and Nigeria's oil and gas regulatory mechanisms. Because factors relevant to gas flaring reduction are wider than only gas flaring regulation, I examine the related oil and gas regulatory and institutional framework, with a view to determining the transferability of the Alberta framework to Nigeria.

The general facts on Nigeria and Alberta's oil and gas industries provide the primary basis for a comparative analysis of both jurisdictions' mechanisms for gas flaring reduction. ${ }^{59} \mathrm{O}$ Oil

David Nelken, "The Meaning of Success in Transnational Legal Transfers" (2001) 19 Windsor Y.B. Access Just. 349.

ibid. at 357.

David H. Breen, Alberta's Petrole'um Indhsiry and the Cemservation Board (Ldmonton: University of Alberta Press, 1993) at liv.

99 For a comprehensive discussion of the background to the Nigerian oil and gas industry, see Sarah Ahmad Khan, Nigeric: The Political Economy of Oil (Oxford: Oxford Universily Press, 1994). 
and gas were discovered in commercial quantities in Nigeria in $1956 .{ }^{60}$ For five decades, revenue from oil and gas has been the mainstay of the Nigerian economy, ${ }^{61}$ and as Nigerian policy-makers contend, the centerpiece of the country's economy in the future will be natural gas and not oil. ${ }^{62}$ However, with every cubic meter of gas flared, Nigeria loses potential revenue, the environment is degraded, ${ }^{63}$ the health of the people proximate to the flares is at risk, ${ }^{64}$ social unrest continues in Nigeria's Niger Delta, ${ }^{65}$ the potential amount of oil recoverable from the reservoirs is reduced, ${ }^{66}$ and a non-renewable resource is lost for all time. ${ }^{67}$

In Alberta, oil and gas production commenced in the Turner Valley field as early as 1913. ${ }^{68}$ Presently, Alberna produces about 70 percent of Canada's crude oil and 80 percent of its natural gas..$^{69} \mathrm{About} 20$ percent of Alberta's natural gas is associated gas. ${ }^{70}$ Alberta, like Nigeria, for many years flared much of its natural gas and still grapples with flaring and venting to a certain extent even today. However, more recently Alberta has substantially reduced the level of gas flaring.

lbid. at 39. Nigeria has an estimated proven oil reserves of about 35.2 billion barrels. The country's natural gas reserve are estimated to be about three times as much as the oil reserves - an estimated 176 trillion cubic fecl ( $\mathrm{el}$ ) of proven natural gas; but this could be as high as $660 \mathrm{tef}$. About half of these gas reserves is associated gas. See Olusegun Obasanjo, "President's Address" (Paper presented to the First Annual Workshop of the Nigerian Gas Association. Abuja. Nigeria. 1 November 1999) [unpublished]: Gaius-Obaseki, supra nole 5; and li: $\mathrm{A}$ 2005, supra nole 6. Petro-dollars accopnt for about 80 percent of govemment revelnue, over 90 percent of foreign exchange carnings, and 96 percent of export earnings. See EIA 2005, ibid. Obasanjo, supra nole 60. Gas flaring is a soufee of acid deposition and a major contributor to increased green house gas emissions and global warming. See generally M. Strosher, Imestigutions of Flare Gas Emissions in Alberta (Calgary: Alberta Research Council. 1996).

The alleged health mpacts of gas flaring emissions include increased risk of chronic respiratory disease, cancer, irritation of the cyes, nose, and throat, and reduced lung capacity. It also reduces the productivity levels of agricullunel crops and forests. See Thomas Marr-Laing \& Chris Severson-Baker, Beyond Ecorerrorism: The Delper Issites Affecting Alberta's Oilpach (Draylon Valley, Alta.: Pembina Institule. 1999).

In 1993, the Ogon i people of the Niger Delta, totaling about 300,000, were involved in the largest demonstration aga nst an oil company (Shell) in history. See Friends of the Earth. "Behind the Shine: The Other Shell Report 2003," online: Friends of the Earth <www.foe.co.uk/resource/reports/ behind_shine.pdif at 7. The expressions of dissatisfaction with the environmental state of the Niger Delta and the effe of s of pollution arising from oil and gas production on the economy and lives of the people still continus.

Because of its premature depletion of reservoir pressure, gas flaring contribules to a reduction in the amount of oil ultintately recoverable from an associated gas reservoir.

6. The discussion of the impacts of gas flaring is outside the puniew of this article. For an analysis. see tbironke Odumos. Reforming Gas Flaring Laws in Nigeria: The Transferability of the Alberta Regulutony framusoork (LL.M. Thesis, University of Calgary, 2005) [unpublished]. See generally. Broen. suppra note 58 for a comprehensive history of the discovery of oil and gas in Alberta. See "What is Natural Cas??," online: Alberta Energy <www.energy.gov.ab.ca/301 asp>.

70 See AEUB, Statistcal Scries (ST) 2004-98, Alberta's Reserves 2003 amd Supply/Demand Oulook 2004$20 / 3$ (May 2004), online: AEUB <www.eub.gov.ab.ca/bbs/producls/STs/s198-2004.pdf>. 


\section{A. Background to the Regulation Of Gas FlaRing REDUCTION IN ALBERTA}

This section discusses general issues in Alberta's oil and gas regulatory schemes that affect the regulation of gas flaring in the province and are relevant to the transferability of its gas flaring laws. Generally, these include provincial and private ownership patterns, legislative jurisdiction, and the scheme for the disposition of oil and gas. Even though relevant to the entire oil and gas industry, these ownership and legislative patterns, and the regulatory scheme for disposing of oil and gas resources, contribute to shaping the gas flaring regulatory climate, as they dictate the rules that are applicable to the industry in general, including gas flaring.

\section{THE OWNERSHIP OF AND LEGiSLATIVE JURISDICTION OVER OIL AND GAS RIGIITS IN ALBERTA}

The 1982 patriation amendments to the Canadian Constiturion Act. 1867" included a significant change on natural resource management. ${ }^{72}$ Section $92 \mathrm{~A}$ confirms the provinces' jurisdiction over the management and disposition of their oil and gas resources, and other non-renewable resources. ${ }^{33}$ There are two oil and gas ownership regimes in Alberta private and Crown ownership. The Alberta Crown owns about 80 percent of the minerais in the province. ${ }^{74}$ Holders of freehold interests in the minerals own the balance. Most of the judicial interpretations of tenure and disposition systems, ${ }^{75}$ as well as early efforts at conservation of natural gas in the Turner Valley, arose in the context of disputes over freehold minerals. But irrespective of the ownership regime, the provincial government regulates the production and conservation of oil and gas resources in the province.

\section{THE SCHEME FOR THF. DISPOSITION OF OIL AND GAS}

Property rights may be created in oil and gas resources in Alberta, by the freehold oil and gas lease, or the Crown oil and gas lease or licence. The right to drill and produce oil and gas from freehold lands within Alberta is negotiated with the private owners through the terms of the freehold lease. ${ }^{76}$ The Mines and Minerals $A c t$ provides for the disposition of publicly

$\because \quad$ (U.K.), $30 \& 31$ Vict., c. 3.

$\because \quad$ Section 50 of the Comstitution Act, 1982, being Schedule B to the Canodu Act 1982 (U.K.), 1982, c. 11 , adds s. 92A to the 1867 Act.

73 See generally, William D. Moull, "Natural Resources: Provineial Proprictary Rights, the Supreme Court of Canada, and the Resource Amendment to the Constitution" (1983) 21 Alta. L. Rev. 472 and William D. Moull, “Section 92A of the Constitution Act, 1867" (1983) 61 Can. Bar Rev. 715.

if Michael Crommelin, "Jurisdiction Over Onshore Oil and Gas in Canada" (1975) 10 U.B.C. L. Rev. 86 at 92. For an analysis of the constitutional history of provincial ownership of natural resources in Canada, see (ierard V. La Forest. Natural Resources and Public Property under the Canadian Constimution (Toronto: University of Toronto Press, 1969).

" Sec, e.g. Bonys v: Canodian Pacific Raihway Co., [1953] 2 D.L.R. 65 (P.C.) and Berkheiser" Berkhciser. [1957] S.C.R. 387 [Berkheiser].

io In Berkheiser, ibid., the Supreme Court of Canada held that the frechold oil and gas lease in question, created a profit a premdre in the lessec. See Alastair R. Lucus \& Constance D. Hunt, Oil and Gas Law in Canada (Toronlo: Carswell, 1990) at 8, for cautionary steps applicable to the Berkheiser interpretation of a frechold lease. 
owned oil and gas resoprces in Alberta. The Minister, on behalf of the Alberta Crown and with the authorization of the Lieutenant Governor in Council, may enter into contracts respecting the recovery of minerals, the processing of the recovered minerals, and the sale or disposition of those minerals. ${ }^{78}$ A Crown oil and gas licence or lease is a statutory permission to explore for, win and work minerals, and a contractual instrument by which the Crown, as owner of the oil and gas in situ, grants property rights to the lessees. ${ }^{79}$

3. THE EHFECTS OA THE OWNERSHIIP STRUCTURE ON GOVIRNMLNT'S REgUI.ATORY CAPACITY

The Alberta Crown is at the same time the proprietor of natural resources and a legislator. ${ }^{80}$ As proprietor, it conveys interests in oil and gas resources that are binding as a matter of contract. In its legislative capacity, the Crown can derogate from its contractual obligations as proprietor as the leases incorporate terms that allow regulatory changes to take effect. By these leases, future legislative amendments are binding on the lessees as a term of the contract. ${ }^{81}$ Harrison argues that the ability of the Crown to include unilateral amendment clauses without scaring away investment is a function of the confidence the oil and gas companies have that the legal mechanism for effecting change will not be used arbitrarily. This confidence has developed over time and is a major factor in the regulatory capacity of the province. ${ }^{82}$

The ownership of, and disposition scheme for, oil and gas in Alberta are factors that affect the regulatory capacity of the Alberta government and the type of regulatory regime adopted. They provide a basis for comparing the general Albertan and Nigerian oil and gas regulatory systems and for determining the factors that need to be considered in contemplating a transfer of Alberta's gas flaring reduction regime to Nigeria.

\section{B. Background to the Regulation Of Gas Fi.ARING in Nigeria}

The ownership and disposition of oil and gas and the regulation of the industry in Nigeria has undergone several changes, beginning with the colonial era. From the 1950 s, events on the international scene, especially the United Nations resolution on Permanent Sovereignty over Natural Resources, ${ }^{\mathrm{k}}$ reshaped the prevailing situation in Nigeria's oil and gas industry. OPEC, of which Nigeria is a member, also encouraged reform of the legislative and administrative frameworks of its members' oil and gas industries.

Bbid., ss, 9(a)(i), 81(1): Petroleum and Natural Gas Tenure Regulation, Alta. Reg. 263/1997, s. 14(1). Spooner Oils Lad. 1: Turner Valle! Gas Consenation Board. [1933] S.C.R. 629. See generally, Andrew R. Thompson, "Legal Characteristics orDisposition Systems: An Overview" in Nigel Bankes \& J. Owen Saunders, eds., Public Disposition of Nonural Resources: Essans from the Fïrst Banff Conference on Natural Resources Law (Calgary: Canadian Institute of Resources Law, 1984) I at 6.

Rowland J. Harrison, "The Legal Character of Petroleum licenees" (1980) 58 Can. Bar Rev. 483 at 484. See s. 2(2)(a)-(b) of Alberta Petroleum and Natural Gas Licence 2003 and tlic Alberta Petroleum and Natural Gas Lease 2003, online: SEC Info <www.secinfo.com/d 1 13j2.2193.9) httm>. See Harrison, ibid. at 505.

Harrison, ibid. at 508.

GA Res. 1803 (XVII), UN (jAOR, 17th Sess., Supp. No. 17, UN Doc. A/5217 (1962) 15. 


\section{THE OWNERSHIP OF AND LECiSLATIVE JURISDICTION OVER}

OIL AND GAS RIGHTS IN NIGERIA

By virtue of the Nigerian Constitution of 1999, the regulation of oil and gas is under the exclusive legislative purview of the federal legislature - the National Assembly. ${ }^{84}$ Apart from the power to make laws, the Constitution also vests proprietary rights in oil and gas in the federal government. ${ }^{\text {gs }}$ There is no private ownership or state/provincial ownership of natural resources in Nigeria.

\section{THE SCHEME FOR THE DisPOSITION OF OIL AND GAS}

The federal government disposes of oil and gas resources through concessions and several types of contracts and agreements. ${ }^{\text {*6 }}$ These include the joint venture (JV) contracts, production-sharing contracts (PSCs), and service contracts(SCs). Each type of oil production contract has the capacity to affect the volume of flared gas through the provisions relating to the rights and obligations of the parties in relation to associated gas. ${ }^{37}$

Under the Petroleum Act, the government grants concessions to operators in the form of Oil Mining Leases (OMLs). The procedure for obtaining the OML involves the granting of several levels of licences in the following order - Oil Exploration Licence (OEL), Oil Prospecting Licence (OPL), and the OML. ${ }^{88}$ The OML is the largest oil and gas right that oil companies can acquire in Nigeria. ${ }^{89}$ The federal government, through the Nigerian National Petroleum Corporation (NNPC), typically acquires a 60 percent participation interest in companies' OMLs through the JV, which is the most common form of oil and gas agreement in Nigeria. ${ }^{90}$

Production from most offshore fields in Nigeria is dealt with under a PSC. Because offshore production is a more expensive venture, a separate contract regime and legislation

See ss. 4(1)-(2) and Schedule II (Pant I, ltem 39) of the Constitution of the Federal Republic of Nigeria (1999) [1999 Constitution].

1999 Constitution, ibid., s. 44(3). Section 1 of the Petroleum Act, (L.F.N. 1990) c. 350 - the primary statute that regulates the exploration and production of oil and gas in Nigeria - also vests ownership and control of all petroleum in the federal government. The sections of the Petroleum Act referred to herein can be found online: Nigeria Law <www.nigeria-law.org/Petroleum\%20Act.htm>.

See Yinka Omonogbe, The Oil and Gas Indusiry: Exploration and Production Contracts (Lagos, Nig.: Malthouse Press, 1997).

8) See Franz Gerner, Bent Svensson \& Sascha Djumena, "Gas Flaring and Venting: A Regulatory Framework and Incentives for (ias Utilization" Public Policy for the Private Sector, Nole No. 279 (Oetober 2004), online: World Bank <hltp://mu.worldbank.org/Documents/PublicPolicyJournal/279Gerner-Svensson-Djumena.pdis.

See Petroleum Act, supra nole 85, s. 2(1)(a)-(b), and Schedule 1, paras. 2-3, 6-8, 13.

Petroleum Act, ibid., s. II, and Schedule I, para. 34. The companies acquire rights akin to a proffi a prendre in the produced petrolcum. See Isabella Okagbue, "The Law and Development of Natural Gas in Nigeria," Nigerian Institute of Advaneed Legal Studies, Oceasional Paper No. 9 (1985) at 10-11 (arguing that the companies acquire rights akin to a profit à prendre in the produced petroleum). But sec, Andrew I. Chukwuemerie, "Ownership of Associated and Discovered Gas in Nigeria Under the Old Joint Venture Contracts" (2003) 27 OPEC Review 9 at 13.

\$) Ahmad Khan, supra note 59 at 67. The NNPC currently holds 55 pereent in Shell Petroleum Development Company's OMLs. See online: Nigerian National Petroleum Corporation (NNPC) <www.petroinfonigeria.com/nnpc.html>. 
- the Deep Offshore and Inland Basin Production Sharing Contracts Decree" — regulates production from these fields. Under a PSC belween the NNPC and an oil producing company, the former is indisputably the owner of the oil and gas. ${ }^{92}$ PSCs are particularly attractive for Nigeria because the NNPC has difficulty in meeting its significant financial burden under the JVs. ${ }^{93}$ The other form of agreement, the SC. is no longer commonly used in Nigeria and, by 2003, only one SC remained. ${ }^{24}$

\section{THE EFFECTS OF THF. OWNERSHIP STRUCTURE ON GOVERNMENT'S REgULATORY CAPACITY}

The nature of the agreements the Nigerian government concludes with oil companies has a major impact on its regulatory effectiveness. Because of the NNPC's JV participation, any regulation would be a regulation of the NNPC, which is an agency of the Nigerian government. This raises questions of institutional bias and lack of independence on the regulatory effectiveness of the Nigerian government with respect to oil and gas production. By one interpretation, it could be argued that the NNPC's participation in each JV implies that it bears the responsibility for flaring about 60 percent of all gas flared in fields covered by JVs in the country. However, JV agreements designate the companies, and not the NNPC, as operators. Further, the companies are required to carry out their operations in accordance with good oilfield practice and in compliance with applicable laws and regulations. ${ }^{95} \mathrm{Yet}$, it is not possible to completely ignore the NNPC's complicity, however remote or minute, in gas flaring in Nigeria.

\section{The Institutional Mechanisms}

This section discusses the distribution of power in Alberta and Nigeria's oil and gas regulatory regimes. I examine the institutional mechanisms that the jurisdictions adopt in regulating the oil and gas industry generally, and gas flaring reduction in particular. These mechanisms generally range from regulatory agencies, government ministries and departments, to even government-owned oil companies. While Nigeria has relied more on ministerial and government departmental regulations, the Alberta system has mostly focused on the regulatory agency model.

Decree No. 9 (1999). The Deep Offshore and Intand Busin Production Sharing (ontracts (Amendment) Decree No. 26 (1999) has amended this legislation. See Lawrence Atsegbua, "The Development and Acquisition of Oil Licences and Leases in Nigcria" (1999) 23 OPEC Revicw 56 at 69. The oil company is engaged as a contractor to explore and produce petroleum for a fee.

93 Atsegbua, supra note 91 at 70.

w See generally on Nigerian SCs, Yinka Omorogbe, Oil and Cias Law in Nigeria (Lagos, Nig.: Malthouse Press, 2003) at 42, 53-54 [Omorngbe, Oil and Gas Law in Nigeria] and Atsegbua, ibid. 


\section{The Alberta INSTITUTIONAL. FrAMEWORK}

\section{a. Founding of the Conservation Boards}

From the first conservation legislation enacted in the province, Alberta has always enlisted the services of an expert, independent regulatory agency in the regulation of its oil and gas resources. These boards regulate both private and publicly owned resources. With the enactment of the Tumer Valley Gas Conservation Act in 1932, the first oil and gas conservation agency, the Turner Valley Gas Conservation Board (TVGCB) was established.

The TVGCB and its successors consisted of members appointed by the Lieutenant Governor in Council who held office for a term or during pleasure and received remuneration fixed from time to time by order-in-council. ${ }^{97}$ Subsequent boards - the Petroleum and Natural Gas Conservation Board, ${ }^{98}$ the Oil and Gas Conservation Board, ${ }^{99}$ and the Energy Resources Conservation Board (ERCB $)^{100}$ — had similar administrative compositions. The boards had wide powers, including the right to employ professional staff necessary to carry out their obligations. ${ }^{101}$ From 1957, the boards acquired exclusive jurisdiction to examine, inquire into, hear, and determine all matters and questions arising under the relevant legislation. ${ }^{102}$ The boards' decisions were final and conclusive, subject to appeals on points of law or jurisdiction, to the Appellate Division of the Supreme Court of Alberta with leave. ${ }^{103}$

Beginning with the TVGCB, independent regulatory agencies have become a permanent feature of Alberta's framework for the regulation of the oil and gas industry. While many factors including technical, market, and political factors contributed to the development of Alberta's gas flaring regulatory regime, the boards stand out as agencies that contributed immensely to curbing incessant wastc and achieving conservation of oil and gas reserves. They applied their legislative and regulatory power to aid gas flaring reduction, established field practice and surveillance mechanisms, and exercised their quasi-judicial decisionmaking power according to the boards' prevailing conservation philosophy at the time.

\section{b. Alberta's Contemporary Institutional Framework}

Several government departments and agencies are charged with the responsibility of ensuring effective compliance with legislation in regulating gas flaring reduction in

S.A. 1932, c. 6, ss. 4(1)-(2) [TVGCA]. I refer to the regulatery agencies discussed in this article as "Board" or by their title.

Sec, e.g., Oil and Gas Resources Conservution Acr, S.A. 1938 (2d Sess.), c. 1, consolidated in R.S.A. 1942. c. 66. s. 6(1) [OGRCA 1938A].

thid, s. 5. The Board adopted a salary policy that separated the Board's professional staft from civil service salary scales and matched industry averages. See Breen, supra note 58 at 505.

w Oil and Gas Conservation Act, S.A. 1957. c. 63, s. 6 [OGCA 1957].

Itwe Energv Resources Conservation Act, S.A. 1971, c. 30 [ERCA 1971].

1u1 OCRCA 1938A, supra note 97, s. 14(a)-(b).

10: OGCA 1957, supra note 99, s. 103.

10. Ibid., s. 112; ERCA 1971, supra nole 100, ss. 40)-43. 
Alberta. ${ }^{104}$ Government formulates policy through legislation while the regulators administer the policy. The current regulatory agency - the AEUB - is a quasi-judicial agency of the Government of Alberta that regulates the production of Alberta's energy resources. ${ }^{105}$ It is a creation of statute, ${ }^{106}$ established as a corporation, and consists of members ${ }^{107}$ and staff. ${ }^{108}$ The AEUB exercises regulatory, approval, policy-making, adjudicatory, and advisory functions ${ }^{109}$ and, in a departure from the norm of delegating rule making functions to Cabinet. the AEUB aiso exercises regulation-making powers under certain statutes. ${ }^{110}$

By virtue of the AEUB's enabling legislation, Board members hold office for an initial term of five years and, afterwards, at the pleasure of the Lieutenant Governor in Council."' The Lieutenant Governor in Council may remove AEUB members from office at any time during the five year term, on the address of the Legislative Assembly. ${ }^{112}$ By the provisions on financial matters in the $E R C A$, the executive and the legislature have statutory obligations in relation to the AEUB's finances. For example, by s. 5(5) of the $E R C A$, the Licutenant Governor in Council fixes the remuneration of Board members. Under the $A E U B A C t$, some actions of the AEUB are subject to the approval of the Licutenant Governor in Council. ${ }^{113}$ The AEUB may delegate any of its powers and duties to its officials and employees, unless the regulations prohibit such delegation. ${ }^{14}$

Without engaging in a substantive and normative analysis of AEUB's work, it is worthwhile, especially for the purpose of comparative analysis, to note that several other themes apply to the AEUB's regulatory approach. These themes include public interest considerations, stakeholder consultation, acquisition of accurate and detailed information, and the adoption of a lair and objective standard. The AEUB adopts a public participation model in its adjudicatory process through its hearings. ${ }^{115}$ It also imposes consultation requirements on companies. The AEUB provides for public involvement and consultation in its application process. AEUB Directive 029: Energl and Utility Development

These include the Ministry of Energy (Alberta Energy) and the Environment Ministry (Alberta Environment).

The AEUB is a regulatory agency subject to all the trappings of inslitutional independence. a subject that is beyond the purview of this article. On the Supreme Coun of Canada's requirements for institutional independence, see Valente v: The Queen. [1985] 2 S.C.R. 673: Ocean Port Hotel l.ed. v. Brifish Columbia (Gieneral Mtanager, Liquor Comtrol and Licensing Branch), 2001 SCC 52, [2001] 2 S.C.R. 781; and Conoutian Pacific l.td. v. Matsqui Indian Band. [1995] I S.C.R. 3. Alberta Energy and Uhilities Board ACl, R.S.A. 2000, c. A-17 [AEUB ACr].

Jbid, ss. 2, 3, 9-11: Energy Resources Conservation Act, R.S.A. 2000, c. F.-10, s. 10 [ERCA].

AEUB Act, ibid, s. 4.

ERCA. supra note 107, s. 2(g).

An example is s. 10 of the Oil and Gas Conservation Act, R.S.A. 2000, c. O-6 [OGCA 2000]. See the Alberta Court of Appeal's decision in Ciann Grosmont Petrolenm Lrd. i: Gulf Canada Resources Lrd. 2001 ABCA 174, 286 A.R. 146, for a judicial opinion on the AFUB's regulation-making powers as well as issues that are inerm vires the Board and pursuant to the statutes that establislied the Board's authority. ERCA, supra note 107 . s. 5 .

Ibid., s. 5(4).

See ss. 20) and 22(2) of the ERCA, ibid. Section 27 of the AEUB Act, supro note 106, states that the aetions, orders, rulings, and decisions of the AEUB are final and cannot be questioned, reviewed, or restrained, subject to judicial review provisions. See also ss. 25 and 41 of the ERCA.

AEUB ACt, ibid., s. 18. But see s. 29(1)(b).

ERCA, supra note 107, s. 26. Hearings are held where the Board is of the view that the rights of persons may be adversely affected. See ss. 8(1). 17(d), 18 regarding examiner hearings. 
Applications and the Hearing Process ${ }^{116}$ requires that everyone potentially affected must work together in an honest manner from the beginning of an energy project and throughout its life. ${ }^{117}$ The appropriate dispute desolution (ADR) system, is one of the mechanisms that the AEUB created to enhance the effectiveness of the regulatory process and give Albertans the opportunity to contribute to issues that affect them. Under the ADR system, parties can choose from a number of options in the resolution of disputes. ${ }^{118}$

The AEUB's institutional framework as an independent quasi-judicial regulatory agency, especially with regard to its rulc-making and monitoring powers, plays a significant role in gas conservation, particularly with the negotiation, publication, application, and enforcement of the gas flaring directive. It stands out as an agency that is central to gas flaring regulation in Alberta.

\section{TIIE NIGERIAN INSTITUTIONAL FRAMEWORK}

Several government agencies are involved in the regulation of the Nigerian natural gas sector. These include the Department of Petroleum Resources (DPR), the Ministry of Petroleum Resources (MPR), the Office of the Presidential Adviser on Petrolcum Matters, the Ministry of Finance, the NNPC, ${ }^{119}$ and the Federal Environmental Protection Agency (FEPA). ${ }^{120}$ The NNPC was established in 1977 as a result of a merger between the then MPR and the Nigerian National Oil Corporation (NNOC), which was established in 1971. ${ }^{121}$ The commercial purposes of the NNOC and the regulatory functions of the MPR were vested in the NNPC. The NNPC's purpose is to engage in exploration, prospecting, mining, and marketing of oil and gas resources in Nigeria. ${ }^{122}$ It is the national oil company and its major role is the indigenization of the oil and gas industry through participation in oil and gas concessions and engaging in wholly-owned petroleum operations. ${ }^{123}$

The law governing the NNPC has remained substantially unchanged while the Corporation itself has undergone three main reorganizations. ${ }^{12+}$ The NNPC assumed a

(January 2003), online: AEUB <www.eub.ca/does/Documents/directives/Directive029.pdis.

Public consultation is a means of ensuring better decisions by the Board, fewer objections, focused hearings, and lairness on the part of the AEUB. See generally. Alastair R. Lucas, "Canadian Participatory Rights in Mining and Energy Resouree Development: The Bridges to Empowernent?" in Donald N. Zillman, A lastuir R. Lucas \& George (Rock) Pring, eds., / hmman Rights in Nanral Resource Development Public Participation in the Sustainable Development of Mining and Energy Resources (Oxford: Oxford University Press, 2002) 305.

11 The ADR process is an avenue for settling disputes between industry and the public and the AEUB acts as the mediator. See AFUB Information Letter 2001-1: Appropriate Dispute Resolution (ADR) Program and Guidelines for Energy Industry Disputes (8 January 2001) and AEUB General Bulletin 2003-22: Clarification of Energy Application Process (24 June 2003).

Ste the Nigerian National Petroleum Corporation Act, (L.F.N. 1990) c. 320 [NNPC ACt].

The enabling statutes for the FF.PA are the Federal Environmental Protection Agency Act, (L.I.N. 1990) c. 131 and the Federal Emironmental Profection Agency (Amendmeml) Decree No. 59 (1992). FEPA administers the Envirommensal Impact Assessment Decree No. 86 (1992). It is responsible for formulating environmental standards and monitoring compliance with such standards.

Decree No. 18 (1971).

Section 5 of the NNPC ACI, supra nole 119 , sets out the purposes of the corporation.

On the role of National Oil Companies, see generally, Michael A. Olorunfemi, "The dynamies of national oil companies" (1991) 15 OPEC Review 321.

1:4 Omorogbe, Oil and Gas Law in Nigeria, supra note 94 at 101. 
commercialized and autonomous status on 1 January 1992, and by a rcorganization in 1988 . twelve strategic business units, including the Nigeria Gas Company, were created. ${ }^{123}$ None of the restructurings had any legislative backing and there is no correlation between the unamended NNPC ACt and the present framework of the NNPC. ${ }^{126}$ Ahmad Khan criticizes the NNPC as an "essentially weak organization" because of its management problems, excessive red tape and burcaucratic delays, and its relationship with the Nigerian Government. ${ }^{121}$ Presently, the NNPC is more of a commercial entity than an industry regulator, in a departure from its former combination of commercial and regulatory functions. ${ }^{12 \times}$

The DPR, the government agency that currently ensures compliance with industry regulations, was set up to supervise and regulate the petroleum industry in Nigeria. The DPR is a department of the MPR. It is organized into eight divisions, each headed by a deputy director. ${ }^{129}$ It has three zonal offices and 14 field offices. Operation controllers supervise the field offices. ${ }^{130}$ The role of the DPR in relation to all petroleum operations, as well as petrochemicals, includes supervising petroleum operations, enforcing environmental regulations, and processing licence applications. ${ }^{131}$

The DPR's problems include insufficient funding and a lack of enabling powers to initiate and implement regulatory measures. In July 2004, the Oil and Gas Implementation Committee (OGIC) recommended that the DPR be granted autonomy to allow it to perform its supervision of the oil and gas industry more effectively. The Petroleum Inspectorate Commission initiated a draft bill to give legal effect to the DPR's autonomy, but this has not been finalized. ${ }^{132}$ Thus, there seems to be a semi-reversal of legislative roles between the NNPC and the DPR. While the statute books include provisions on the NNPC's statutory power to regulate, this is no longer available in practice as this role has been transferred to the DPR, which lacks a separate explicit enabling legislative mandate.

\section{The Regulatory Practices}

Generally in the oil and gas industry, the principal method of gas flaring regulation is to develop rules on, and effect compliance with, conservation practices. Conservation has two principal definitions, the one founded on economics and the other on geological

The Privatisation and Commerciulisution Act. (L.F.N. 1990) c. 369 listed the NNPC as one of the government-owned enterprises to be commercialized.

Sec Omorogbe. (il and Gas Law in Nigeria, supra note 94 at 103 for the several inconsistencies in the government's administration of the NNPC and the NNPC Act. Currently, the NNPC has ten whollyowned subsidiaries. two parly-owned subsidiaries, four directorates, and 19 associated companies. Sec "About NNPC Structure," online: Nigerian National Petroleum Corporation <www.nnpcgroup.com/ aboutus.htm>.

See NNPC Act. supro note 119. s. 10, for the provisions on the Petroleum Inspectorate, which was the regulatory arm of the NNPC.

These divisions are personnel management: supplies: economics, plans, and statistics; safety and environment: finance and accounts; resources management; engineering and standards; and inspection. "Organization and Key Management," online: DPR <www.dpmigeria.com/management.html>.

"Functions \& Responsibilities," online: DPR <www.dpmigeria.com/dpr_roles.html>.

Onycbuchi Ezigbo, "FG May Gant DPR Autonomy" This Day Newspaper (Nig.)(21 July 2004), online:

This Day Online <www, thisdayonline,com/archive/2004/07/22/20040722News 14.html>. 
connotations. ${ }^{133}$ Between these two definitions, eliminating waste is a principal consideration. Conservation involves responsible development of natural resources in a manner most beneficial to the present generation and posterity. This mode of regulation has featured prominently in Alberta's oil and gas industry. In this section, I discuss the actual regulatory practices that Alberta and Nigeria have employed in curbing gas flaring in their respective jurisdictions.

\section{Alberta's Conservation Practicles}

If Alberta has nothing else in its favour with regard to gas flaring regulation, it does possess a rich history. Because the Alberta gas flaring regulatory mechanism is almost a century old, assuming it is feasible to adopt some part of Alberta's gas flaring reduction system in Nigeria, it is important to briefly outline this historical development. This outline is necessary for determining whether Nigeria should adopt older Alberta practices rather than prematurely adopting Alberta's present framework without approaching its development in a systematic manner.

At the time natural gas in commercial quantities was first discovered in Alberta, companies regarded the resource as waste incidental to oil production and flared it. ${ }^{134}$ However, based on scientific knowledge of the damage caused by gas flaring to reservoirs, lessons learned from jurisdictions with mature oil industries, and after some degree of administrative wrangling, Alberta was able to establish a regulatory regime to curb gas flaring. ${ }^{135}$ This creation involved the enactment of conservation legislation and the establishment of conservation boards to administer the regulations. This regime has expanded over the years and there have been several amendments to the initial regulatory framework.

\section{a. The Development of a Regulatory Framework for Gas Flaring Reduction}

In the first decades of gas conservation regulation in Alberta, the major regulatory themes included reducing production quotas, pro-rationing, prescribing the daily rate of production, laying a solid foundation for field practice, working with a comprehensive definition of waste, and criminalizing waste and making it an actionable tort. ${ }^{136}$ The regulatory boards had wide discretion in these decisions and very broad powers. These powers included the determination of efficient methods of effecting gas conservation and shutting in noncomplying wells, or wells that produced gas for which there were no utilization outlets. ${ }^{137} \mathrm{~A}$ recurring theme was effecting gas conservation in accordance with sound engineering

See Erich W.Zimmermann, Conservation in the Production of Petroleum: A Study in Industrial Control (New Haven, Conn.: Yale University Press, 1957) at 24; Wallace F. Lovejoy \& Paul 1. Itoman, Economic Aspecis of Oif Conservetion Regulation (Ballimore: Johns Hopkins Press. 1967); and Maurice J. Sychuk, "Conservation: Is it Justified in the P'ublic Interest?" (1969) 7 Alta. L. Rev. 355. Breen, stupres nole 58 at $x$ lix.

113 Alberta derived some lessons from the Calitomian experience in gas llaring reduction, especially in developing a technical approach to the problem. See ibid. at 57-58.

in See TVGCA, supra note 96, s. 13: OGRCA 1938A, supra nole 97; Oil and Gas Resources Conservation Act, 1950, S.A 1950, c. 46; OGCA 1957, supra note 99; and Oil and Gas Conservation Act. 1969. S.A. 1969, c. 83.

1: See, e.g., TVGCA, ibid, s. 15(2)(c) and OGCA 1957, ibid., s. 40. 
principles and economics. Where this was not feasible, the relevant wells could be exempted from complying with waste avoidance regulations. ${ }^{138}$

Beginning from the 1950s, the boards issued gas conservation (GC) orders on grounds that it was in the public interest to prevent waste and to process all produced gas. ${ }^{139}$ Because the orders were specific to particular oil and gas fields, the boards could set maximum flaring limits according to the peculiarities of each field. Hundreds of non-complying wells that were not exempted were shut in for solution gas flaring. ${ }^{1+n}$ Other gas conservation methods that have been adopted in Alberta apart from the GC orders include maximum rate limitations (MRL), production penalties based on exceeding gas-oil ratio (GOR) limits, and surveillance. ${ }^{141}$

Throughout the early periods, the regulatory boards required conservation unless it was not economically or technically practicable. The exception to economic and technical practicality is overriding environmental and/or public complaints issues. ${ }^{142}$ The boards have regarded conservation in those cases as "a cost of doing business." development of Alberta's gas flaring reduction framework has been the commitment of the leaders of the regulatory agencies and the government to effect conservation of the province's oil and gas resources. ${ }^{1+4}$

\section{b. The Contemporary Framework for Gas Flaring Reduction}

In ensuring the reduction and eventual elimination of gas flaring in the present dispensation, the AEUB has adopted several principles. These principles include enhanced regulation and enforcement, a consensus-based flaring management framework, industry compliance and cooperation, and collaboration through organizations that work with the AEUB on gas flaring issues. ${ }^{145}$ This section outlines the current gas flaring reduction framework that has enabled Alberta to achieve a substantial level of natural gas conservation.

See, e.g., OGCA 1957, ibid., s. 2(u)(v).

Set, e.g., Order No. G.C. 1: Order No. GC 46 (23 March 1967), Order No. GC 50 (29 February 1968) and Order No. GC 87 (9 A pril 1986). Available at AEUB's Information Resources. The Board issued $87 \mathrm{GC}$ Orders between 1953 and 1986 , when the last was issued.

Breen, supra note 58 at 527.

The GOR is the amount of gas that is produced with every barrel of oil. The AEUB still adopts MRLs and GOR production penalties. See generally in relation to these conservation methods, Eric P. Moeller. "Gas Conservation in Alberta" (laper presented to the Ontario Petroleum Institule 29ih Anuual Conference, London, Ontario, 14-16 November 1990) at 4 [unpublished].

Ibid. at 5 .

thid.

Sec Breen, supra note 58 at 243.

AEUB, Statistical Series (ST) 2004-06B, Upstream Petroleum Indessiry Flaring and Venting Report. 2003 (May 2004) at 3. The AFUB works with the Clean Air Strategic Alliance (CASA), the Cannadian Association of Petroleum Producers (CAPP), the Simall Explorers and Producers Association of Canada (SEPAC), the Alberta Department of Resource Development (ADRD), and Alberta Environment on gas flaring reduction. 
The contemporary framework for gas flaring reduction includes provisions under the Oil and Gas Conservation $A c t^{1+6}$ and AEUB directives, legislative and extra-legislative incentives for gas conservation, and the institutional mechanism set up by the government. The $O G C A$ and regulations made pursuant to it $^{147}$ were enacted to achieve several goals including conservation and preventing the waste of oil and gas resources in the public interest. ${ }^{14}$ The $O G C A$ does not define conservation but defines waste and wasteful operations. ${ }^{149}$ Gas flaring may not constitute wasteful operations under the provisions of the $O G C A$ where it cannot be prevented, having regard to sound engineering principles and the economics of conservation. In general, according to its public interest mandate, the AEUB is to have regard to the social, economic, and environmental effects of projects. ${ }^{150}$ As a result, the AEUB does not consider projects in isolation, but situates them within these broader contexts in determining their viability and effects on the public.

Under the OGCA, the AEUB retains the power to pro-ration production, restrict the amount of oil and gas that operators may produce, ${ }^{13 i}$ and require enhanced recovery operations in a pool. It may also require the gathering, processing, marketing, or injection of gas into an underground reservoir for storage or for any purpose. ${ }^{152}$ As a means of air pollution control, the $O G C R$ requires that, absent emergencies, lessees cannot burn gas except under conditions of controlled combustion where there is no significant or visible emission of smoke. ${ }^{153}$ The $O G C R$ includes air pollution control even though environmental and pollution control is within the jurisdiction of Alberta Environment. Alberta Environment and the AEUB adopt a "one window" approach for coordinating environmental assessments and approvals. Under the "one window" process, each government department checks that a specific application meets its own regulations and standards. Any deficiencies or concerns are forwarded to the AEUB through Alberta Environment. ${ }^{154}$

$O G C A 2000$, stupra note 110. I refer to this version of the $O G C A$ as the $O G C A 2000$ for ease of reference (as I have cited earlier versions of the $A(t)$ ) and not because the $A c t$ came into foree in 2000 . The last major re-cnactment of the OGCA was in 1969. Since this time, there have been several amendments to the $A C t$, and consolidations in 1970, 1980, and 2000. The 2000 consolidation is the latest consolidation. Oil and Gas Consenvation Regulations. Alta. Reg. 151/1971 [OGCR].

OGCA 2000, supra note 110, s. 4(a)-(I).

lbid., s. I ( I)(cec)-(ddd). Gas flaring is regarded as wasteful operations.

See s. 3 of the ERCA, supra note 107 and s. 4 of the OGCA 2000, ibid. See also AEUB Decision 2003 101: Polaris Resources Ldd. Applications for a Well Licence. Special Gas Well Spacing. Compulsony Pooling. and Flaring Permit Livingston Field (16 December 2003), online: AEUB <www. cub.ca/docs/Documents/decisions/2003/2003-101.pdf \$. The AEUB has shifled from the best practical technology to best available technology standard. Sce ERCB Decision 82-12: Esso Resources Canada Lud. Quirk Creek Gas Processing Plam (7 May 1982) and AEUB Decision 2005-016: Canadian Natural Resources Lid.. Appliculions for Well Licences and a Batteny' (15 March 2005), online: AEUB <www, eub.ca/docs/documents/decisions/2005/2005-016.pdß). OGCA 2000, supra note 110. s. 34(1).

Ibid., s. 38(a)-(b).

OGCR. supra note 147, ss. 7.040(1)-(2).

See generally Francis M. Saville and Richard A. Neufeld. "The Energy Resources Conservation Board of Alberta and Environmental Protection" (1989) 2 Can. J. Admin. L. \& Prac. 287. For a description of the "one window" process, see Albert J. Hudec \& Joni R. Paulus, "Current Environmental Regulation of the Alberta Oil and Gas Industry and Enterging Issues" (1990) 28 Alta. L. Rev. 171. 
The $O G C R$ addresses general oil and gas regulatory issues but does not include comprehensive provisions sufficient to regulate gas flaring. ${ }^{15 s}$ As a result, AEUB Directive 060: Upstream Petroleum Industry, Flaring. Incinerating and Venting (2006) is the province's major document on gas flaring regulation. ${ }^{156}$ Directive 060 sets out Alberta's requirements and expectations for upstream petroleum industry flaring. ${ }^{157}$ It establishes requirements on solution gas management, well test flaring, gas battery flaring, gas plant flaring, and pipeline emissions. ${ }^{158}$ It also includes provisions on flare performance requirements, measurement and reporting of flared gas, industry performance requirements, and enforcement. Most of Directive 060's provisions discussed in this article focus on routine solution/associated gas flaring management because this accounts for most of the flared gas in Alberta. This statement is also true of Nigeria.

Directive 060 defines conservation as "the recovery of solution gas for use as fuel for production facilities, for other useful purposes (e.g., power generation), for sale, or for injection into an oil or gas pool." 154 Combustion of solution gas in incinerators and other closed burners, along with venting, are not acceptable alternatives to conservation. ${ }^{160}$ Conservation opportunities are evaluated as economic or uneconomic based on the parameters set out in the directive.

The drafters of Directive 060 developed a flaring management decision tree from the objective hierarchy on gas flaring management. ${ }^{161}$ On this tree, where elimination is possible, the directive requires operators to implement it. Where not feasible, having regard to economic and technical factors, it requires a reduction that must meet flare performance requirements. Where flares cannot be immediately eliminated, the AEUB has expressed its support for the use of alternatives to conventional flare technology. These include enclosed flares and incinerators where these can better achieve efficient combustion. ${ }^{162}$ The Directive provides that licensees are required to adopt best engineering practices in the design of flare systems. ${ }^{163}$ If using the economic decision process detailed in s. 2.8 , conservation is determined to be economic and the AEUB requires gas conservation. ${ }^{164}$ In assessing a decision to flare gas or conserve it, operators are to consider economic, social, and environmental factors. Where producers exceed gas flaring limits in any particular year, the AEUB will impose reductions that will stipulate maximum solution gas flaring limits for

However, it does include some provisions on gas flaring. See $O G C R$, supra note 147, s. 11.135(1).

ist (November 2006), online: EUB < www.eub.ca/docs/documents/directives/Directive060.pdP [Directive 0602006 ). Several versions of Directive 060 (1999, 2001 and 2002) exisled before Directive 0602006. These documents were consolidated into the current version of the Directive.

In Directive 060, the word "must" is interpreted to mean a requirement for which compliance is required and subject to EUB enforcement, and "recommends" indicales a best practice that the applicable part may adopt but is not an EUB requirement and does not carry enforecenent consequences. See Directive 0602006 , ibid., s. 1.5 .

Directive 0602006 , ibid., ss. 2-6.

lbid., s. 2.

Ibid., s. 2. Eflicient combustion through flaring converts the gas to $\mathrm{CO}_{2}$ and it is more environmentally benign than disposing of the gas through venting. See Directive 0602006 , ibid. al 9, lig. 2.

thid., s. 7.1 .

lbid.

Economic considefations emerge as the major determinant for gas flaring or conservation under the Directive. See $i b i d$, s. 2.8.1. 
operating sites. ${ }^{165}$ Oil wells with high GORs are subject to more specific rules. Where a well's GOR is greater than $3000 \mathrm{~m}^{3} / \mathrm{m}^{3}$, the well must be shut in until the lessee conserves the gas. ${ }^{166} \mathrm{~A}$ MRL governs production from new oil pools. The AEUB imposes the MRL until the licensee and the AEUB have agreed on an optimum pool depletion strategy. ${ }^{167}$

On procedural issues, the Dircctive requires personal consultation with residents proximate to the flare site and public notification of flaring. ${ }^{168}$ Directive 060 also requires operators to report the amount of gas flared ${ }^{169}$ and the AEUB undertakes to provide an annual summary of industry flaring emission as part of an industry performance reporting. ${ }^{170}$

Directive 0602006 (including its predecessor gas flaring Directives) has been instrumental in gas flaring reduction in Alberta. One of its utilities lies in the inclusion of gas flaring reduction requirements in one document and its capacity to aid clarity, although the Directive in itself is not exhaustive, as a host of regulatory requirements on matters related to gas flaring regulation in other documents remain applicable. In addition, Directive 060 is subject to continuous improvement and this provides the opportunity for constant review, to incorporate newly conducted rescarch results and relevant developments in the industry.

\section{(ii) Legislative and Extra-legislative Incentives for Natural Gas Conscrvation}

Apart from the regulatory requirements, the province provides other measures and incentives to make natural gas conservation more attractive to industry. Some of these measures, such as the availability of natural gas markets, are necessary for reducing solution gas flaring, while royalty incentives are deliberate policy measures to aid the reduction of gas flaring. ${ }^{171}$

The United States is Alberta's biggest natural gas market. Annually, Alberta producers export about half of the gas produced to the United States. An extensive pipeline infrastructure exists that aids the export of produced natural gas to the United States. About one-quarter of the natural gas produced in Alberta is exported to other parts of Canada. The remaining one-quarter is put to diverse use within the province. Alberta's Rural Gas Program, has the largest rural gas pipeline system in the world, with over $110,000 \mathrm{~km}$ of natural gas pipelines. ${ }^{172}$ On its part, Directive 060 recognizes that one of the ways to reduce flared gas is to generate electricity with the otherwise flared solution gas. ${ }^{173}$

Ibid., s. 2.1.

Ibid., s. 2.5.

Ibid.

Jbid., s. 2.9.

Ibid., s. 2.13.1.

Ibid., s. 2.13.2.

AEUB Infurmation Lelter 99-19: Othenvise Flared Solution Gas Royalty Waiver Program (11 June 1999). By this program, the Ministry of Energy waives royalty on uneconomic solution gas when used in a manner that would normally attract the payment of royalty.

Sec generally "Natural Gas," online: Alberta Energy <www.energy.gov.ab.ca/222.asp>.

Direclive 060 2006, supra note 156, s. 2.7. The Flare Gus Generation Regulation, Alta. Reg. 163/2003 made pursuant to the Electric Utilities Act, R.S.A. 2000, c. E-5 makes specific provisions for the use of flared gas in electricity generation. 
These several mear s of utilizing otherwise flared natural gas - whether through availability and proximity of markets or government facilitated incentives - are necessary to ensure elimination or reduction of gas flaring in the province. The ready markets and extensive infrastructure provide an avenue for putting to economic use the gas that would otherwise have been flared.

\section{c. Enforcement Procedures}

Generally, as part of the AEUB's monitoring process, an operator requires a licence before drilling a well, or either constructing or operating facilities. ${ }^{174}$ Also, the $O G C A$ prohibits waste and makes it an offence to commit waste. ${ }^{175}$ The AEUB may commence and maintain an action to prevent waste for contravention of any of its orders or directions. ${ }^{176}$ In addition, the contravention of any provision of the $O G C A$, the regulations, any order or direction of the AEUB, or any term or condition of a licence granted under the $O G C A$ is an offence. ${ }^{177}$

Under the general AEUB Compliance Assurance-Enforcement, the Board sets the initial enforcement step according to the severity of the non-compliance, and enforcement action may be escalated. ${ }^{178}$ Directive 060 comprises two categories of initial non-compliance events - low and high risk non-compliance - which are determined by a risk assessment matrix. The ratings are based on health and safety, environmental impact, conservation, and stakeholder confidence in the regulatory process. Directive 060 provides actions that need to be taken based on the assessment. The AEUB may take the corrective action itself and charge the costs to the operator as a means of ensuring compliance. ${ }^{179}$

Directive 060 provides compliance and enforcement requirements for gas flaring reduction. Several aspects of the management framework form the focus of the AEUB's enforcement efforts: the review of existing flares; completion of the required personal consultation and public notification; compliance with the flare performance requirements; reducing flaring at conserving facilities; and accurate reporting of flare and vent data. ${ }^{180}$ There have been no major events requiring AEUB enforcement since Directive 060 came into force. Generally, industry compliance with the Directive's provisions has been voluntary and the companies have met the targets set by the AEUB, making it unnecessary to impose any compulsory regulatory enforcement. ${ }^{181}$

17) OGCA 2000, supra note 110, ss. 11(1), 12, 15, 25. The Board may cancel or suspend a licence or approval if il delermines that a contravention of the $O G C A$, the regulations, or an order or direction of the Board has occurred with respect to the well or facility to which the licence or approval relates.

iss Ibid.s ss. 107(1). 108(1).

1io Ibid., s. 107(5). Prosecution under the Act does not preclude an action in tort by an injured party who has suffered damage, against the person committing waste. Sec ibid., s. 107(4).

in lhid., s. $108(2)$. See s. $110(1)$ for punishment for offences under the $O G(C A$.

17 AEUB Dinective 019: EUB Compliance Assurance - Enforcemen (20 lebruary 2007): Directive 060 2006, supra note 156, s. 12.1 .

iv See AEUB Decision 2003-029: Prince Resource Corporation. Review of Abandonment Costs Order No. ACO 200/-06(28 April 2003), online: A EUB <www.cub.ca/docs/documents/decisions/2003/2003-029. pdß.

140 Sec also Directive 0602006, stupra note 156 , s. 12.

18t The consensus-based nule-making process, to which industry is a party. could enhance the level of operators" compliance. 
In sum, Alberta has taken dillerent steps to conserve natural gas, as appropriate, having regard to the circumstances prevailing at the particular time. The province has achieved a high level of conservation in the period since it has adopted the stakeholder consultation approach. The institutional framework of the AEUB, its expert field staff, and several methods of regulation adopted are also instrumental to the level of conservation that the province has achicved. In all. a complex web of factors and regulatory mechanisms make up Alberta's framework for the conservation of natural gas.

\section{NIGERIA'S RIGULATORY PRACTICES}

\section{a. Efforts at Developing a Regulatory Regime for Gas Flaring Reduction}

Unlike Alberta oil and gas legislation, conservation has not been a major feature of oil and gas regulation in Nigeria. Rather, regulators have relied on legislation with no specific conservation theme. The first oil and gas legislation in Nigeria was the Petroleum Ordinance of 1889 , followed by the Mineral Regulation (Oil) Ordinance of 1907, which provided the basic framework for the development of petroleum resources. ${ }^{182}$ These early laws were primarily concerned with the discovery of petroleum and the vesting of ownership in the Crown. ${ }^{1 \mathrm{3} 3}$ The regulatory yardstick was safe and good oilfield practice in accordance with standards then applicable in the oil industry. ${ }^{1 \times 4}$ These statutes and regulations did not substantially regulate production since the first commercial discovery of oil and gas did not occur until 1956.

The Petroleum Act 1969 was, and is still, the most comprehensive legislation on oil and gas exploration and production in Nigeria. The Petroleum (Drilling and Production) Regulutions. ${ }^{185}$ made pursuant to the Petroleum Act provide the main framework for regulating oil and gas production. Specitic pollution control regulations include reg. 25 . which requires the licensee or lessee to "adopt all practicable precautions." This includes the "provision of up-to-date equipment" to prevent pollution, and where such pollution has occurred, to "take prompt steps to control" and, if possible, end it. The only express provision on conservation in the Regulations - reg. 43 - states that the Director of Petroleum Resources may exercise discretion by giving directions to encourage good conservation practices. This is not to imply that some standard conservation practices are not required. For example, reg. 47 requires unitization and joint development of reservoirs. ${ }^{186}$

Also, the major natural gas-specilic provision is reg. 42. It provides that not later than five years after the commencement of production, the licensee or lessee shall submit to the

18: Omoroghe, Oil and Gas Lan in Nigeric, smpra nole 94 at 16.

Ik3 See C. Etikerentse, Nigerian Pe'trolewm Law' (London: Macmillan Publishers, 1985) at 2 for a list these laws.

ist Alsegbuil, stupra note 91 at 58.

ixe The Regulations are made pursuant to s. 9 of the l'etroleum sct, supra note 85.

Ist Omoroghe has commented that "the fact that nothing concrete is said on conservation stems from the fact that Nigeria has nol practiced any conservation policy in the management of her oil resources, and production has followed the greal demands of the economy." See Yinka Omorogbe, "Tlic Legal Framework for the Production of Petroleum in Nigeria" (1987) 5 J. Energy \& Nat'1 Res. L. 273 at 275 [footnote omilted] [Omorogbe, "L.egal Framework"]. 
Minister any feasibility study, programme, or proposals that it may have for the utilization of any natural gas that has been discovered in the relevant area. ${ }^{187}$

The major statute addressing gas flaring reduction in Nigeria is the Associated Gas ReInjection Act $(A G R A),{ }^{18}$ which applies to all associated gas in lands as defined in the Petroleum $A \mathrm{ct}$ and the Exclusive Economic Zone (EEZ). ${ }^{\text {(') }}$ The $A G R A$, passed on 28 September $1979,{ }^{19 \%}$ requires that notwithstanding the provision of reg. 42 of the Petroleum (Drilling and Production) Regulations, all oil and gas producing companies in Nigeria shall submit a preliminary program providing schemes for the viable utilization of associated gas and projects to re-inject all non-utilized associated gas not later than 1 April 1984. ${ }^{191}$ This section of the Act transformed reg. 42 into a mandatory provision. By s. $3(2)$, the Commissioner can issue a certificate exempting companies from the provisions of the $A c t$ where gas re-injection is inappropriate or not feasible, subject to any conditions that may be imposed. Except where authorized, flaring after 1 January 1984 was an offence ${ }^{192}$ and the penalty was forfeiture of the concessions in the fields where the offence was committed. ${ }^{193}$

Under the Associated Gas Re-Injection (Continued Flaring of Gas) Regulations 1984, ${ }^{194}$ one or more of the conditions set out by the Regulations had to be fulfilled for the issuance of a certificate for continued flaring of gas at a given field. ${ }^{145}$ By the Associated Gas ReInjection (Amendment) A ct $1985,{ }^{196}$ the Minister can issue a certificate permitting companies to continue flaring associated gas as long as the company pays such sum as the Minister may from time to time prescribe per unit of gas flared. ${ }^{197}$ The fine regime remains in Nigeria's statute books and it provides a rationale for complacency on the part of the oil producing companies. It also makes the economics of gas flaring in Nigeria tilt very heavily in favour of continued flaring.

Chukwuemerie, stipra nole 89 at 14, eriticizes the dralting of reg. 42 because it does not impose a duty on the lessee as the phrase "may have" is not usually read as "must have" in Nigerian jurisprudence. See PIPDC LA. 1: Philip Eblota and 5 Ors (2001), 64 F.W.L.R. 374.

Decree No. 99 (1979) (AGRA 1979); (L.J.N. 1990) c. 26 (AGRA 1990).

AGRA 1979, ibid., s. 6. At the time the $A G R A$ entered into force, the Petroleum Act did not apply to the EEZ. It only applic to the EEZ as a result of the Petrolerm (Amendment) Act 1998, Decree No. 22 (1998).

See M. Kassim-Momodu, "Gas Re-injection and the Nigerian Oil Industry" (1986/87)6 \& 7 Journal of Private \& Property Law 69 at 80 lor Mobil Producing Nigeria's elforts at gas re-injection before the enactment of the $A C R A$.

AGRA 1979, supro hote 188, s. 1.

lbid., s. 3(3).

Ibid., s. 4(1).

Supplement to Official Gazetle No. 67 Vol. 7I, 29 November 1984 - Part B; S.l. 43 of 1984.

Sec ibid., s. I(a)-(c)'.

Decree No. 7 (1985) [1985 Amendment]; AGRA 1990, stuwa note 188.

1985 Amendment, ibid., s. 3(2)(b). By 1 January 1985, the Act and regulations had the cumulative effect of excmpting 86 out of 155 oil tields and the remaining were subject to a meagre line of 2.5 American cents per 1000 cubic feet of gas flared. See Omorogbe, "Legal Framework," supra note 186 at 286. In 1986, Gulf Oil stated that while gas flaring will cost the company USS 1 million in fines, the capital costs of gas re-injection vould cost an "unacceptable" US\$56 million (Ahmad Khan, supra note 59 at 162). 
There has been little gas re-injection in Nigeria and the government has not revoked any concessions. ${ }^{19 k}$ The government backpedaled on its threats to revoke concessions, perhaps because it lacks the financial capacity or is unwilling to contribute its 60 percent share of the re-injection schemes. The measure adopted was to increase fines that the NNPC is not required to pay in spite of the fact that it is a JV partner. ${ }^{199}$ Even though the government has increased the fincs, it is still more cost effective to pay the fines than to re-inject associated gas. With a recent decision of the Federal High Court of Nigeria (Benin Judicial Division), it seems that the judiciary is beginning to adopt a different perspective on gas flaring. The Court in Gbemre v. Shell Petroleum Development Co. found that the AGRA's provisions allowing continued flaring on the payment of fines amounts to a violation of the constitutional provisions on the right to life and are unconstitutional, null, and void. ${ }^{200}$ The $A G R A$, however, still remains in the statute books, pending appeal of the decision.

\section{b. The Challenges, Successes, and Failures}

Revenuc from oil and gas production is the mainstay of the Nigerian economy. In a bid to maintain this revenue flow, the government sometimes condones actions unfavourable to long-term conservation and environmental protection. Also, the inaccessibility of natural gas markets is a major factor that contributes to gas flaring in Nigeria. At the time the $A G R A$ was enacted, the government could not insist on utilization because of the inaccessibility of markets. The lack of infrastructure necessary for utilization and industry's unwillingness to invest in gas utilization also impede gas flaring reduction. ${ }^{201}$ The NNPC's participation in oil companies' operations comes with obligations and enormous financial responsibilities. In addition, NNPC's JV involvement largely renders any regulator in the Nigerian oil and gas industry toothless and raises issues of regulatory efficiency and independence. Perhaps, the better option in order to aid regulatory effectiveness is to enter into production-sharing contracts with oil companies rather than JVs.

The principal laws regulating the Nigerian oil and gas industry have not been substantially amended in recent times to reflect technical changes that the gas sector requires. Apart from the $A G R A$, which on its own is insufficient to meet the regulatory demands of the Nigerian gas sector, there is only scant legislation on natural gas production in Nigeria. The Petroletum $A c t$ includes scant provisions on gas conservation and government policy on gas production is unclear. However, the provision of financial incentives and gas utilization opportunities seem to have contributed to the achievement of some, albeit small, level of reduction in gas flaring levels. I describe these developments in the next section.

Kassim-Momodu, supra notc 190 at 83 attributes this to concentration on cconomic growth. Writers also accuse the judiciary of giving tremendous weight to the fact that an adverse decision against oil companies might hur the economy. See, e.g., Chinda v. Shell BP. [1974] 2 R.S.L.R. I and Kaniye S.A. Ebcku. "Judicial Altitudes to Redress for Oil-Related Environmental Damage in Nigeria" (2003) 12 R.E.C.I.E.L. 199 at 202.

iw Omorogbe, Oil and Gas Law in Nigeria, stupra note 94 at 60.

:o Suit No: FIIC/B/CS/53/05. Federal High Coun of Nigeria (Benin Judicial Division), online: Climate Justice <www.climatelaw.org/media/media/gas.flaring.suit.nov2005/ni.shell.nov05.judgment.pdis [Gbemre].

:v' Ahmad Khan, supra note 59 at 160 states that the utilization costs of associated gas is ten times higher than that of non-associaled gas. 


\section{c. The Contemporary Framework}

Even though the legislative provisions in the Petroleum Act and the $A G R A$ remain substantially the same to date, there has been a marked departure from the Nigerian government's former command and control approach to gas flaring reduction. After the last amendment to the $A G R A$ in 1985, the Government intensified its efforts to provide outlets for gas utilization and incentives to oil producing companies in order to achieve the desired results - an approach that has been termed "pro-gas utilization rather than anti-gas flaring." 202 The incentives are necessary due in part to the peculiar nature of the Nigerian oil and gas fields. Nigerian fields are small, scattered, and localed in the swampy terrain of the delta, where it is difficult to establish gas utilization facilitics. Another reason for the incentives is the capital intensive nature of associated gas utilization.

The major laws incorporating incentives for gas utilization in Nigeria are the Finance (Miscellaneous Taxation Provisions) Decree ${ }^{203}$ and the Finunce (Miscellaneous Taxation Provisions) (No. 2) Decree. ${ }^{204}$ The effect of these laws is to provide fiscal incentives to both downstream and upstream companies engaged in gas utilization, whether for domestic or industrial purposes. The incentives include taxation of the companies at the Companies Income Tax $A c t^{205}$ rate of 30 percent instead of under the Petrolenim Profit Tax Act ${ }^{206}$ rate of 85 percent; an initial tax holiday period of three years, with a possible renewal for another three years; and deductibility of interest on loans for gas projects provided the approval of the Federal Ministry of Finance is obtained before the loan is taken. ${ }^{207}$ Additionally, gas is transferred from upstream to downstream locations or from natural gas liquids extraction facilities to gas-to-liquid facilities at 0 percent petroleum profit tax and 0 percent royalty. ${ }^{20 x}$

Other financial incentives include the provisions of the Oil and Gas Export Free Zone Decree $^{209}$ that creates an Export Free Zone (EFZ) to encourage investment in gas utilization. Enterprises operating in the EFZ, and approved by the Oil and Gas Export Free Zone Authority, are exempted from all taxes and levies imposed by the different levels of government in Nigeria. There are also capital-intensive gas utilization projects underway in Nigeria including the US\$3.8 billion Nigeria Liquefied Natural Gas (NLNG) project. The NLNG investors are profected by the provisions of the Nigeria LNG (Fiscal Incentives, Guarantees and Assirimecss) Decree. ${ }^{210}$

\begin{tabular}{ll} 
& \\
\hline so2 & Ahmad Khan, supra note 59 at 163. \\
sol Decree No. 18 (1998). &
\end{tabular}

Decree No. 19 (1998). These statutes gave the Associoled Gas fiscal Imcentives Arrangement 1992, which embodied associaled gas specific incentives, legislative force.

(L.F.N. 1990) c. 60.

(L.F.N. 1990) c. 354.

See George Nnona. "New Policy Regime for Gas in Nigcria: $A$ P'erspective on Tax and Related Incentives" (20013) 21 J.E.R.L. 285 at 288-289.

Jhid. at $28 \%$.

Decree No. 8 (1996), amended in 1998 and consolidaled in 1999.

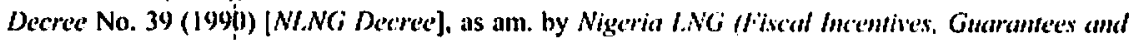
Assurances) Decree No. 113 (1993). The legislation grants the NI.NC ( Company, tax and other linancial ineentives and exempts it from several regulatory approvals. (iiven the provisions of the NLNG Decree, especially the stabilization and arbitration elauses, the legislation represents a foreign investment contract enacted and given the force of law in Nigeria. 
The gas utilization incentives regime has spurred significant investments in the oil and gas industry. The nascent democratic institutions in the country have also gone a long way to encourage investors to undertake capital-intensive gas utilization projects. However, in spite of the gas utilization projects and financial incentives described in this section, only 15 percent of Nigeria's gas reserves are committed, ${ }^{21}$ and the country is still regarded as having one of the highest levels of gas flaring in the world.

\section{d. Enforcement Procedures}

The DPR is responsible for the enforcement of oil and gas laws in Nigeria. Because the DPR is an arm of the MPR, the Minister responsible for the MPR or, in the absence of a Minister, the person designated, is in charge of enforcing the legislation and regulations. Each piece of legislation, for example the AGRA and the Perroleum Act, which are the principal enactments relating to gas flaring regulation, vests the responsibility for enforcing its provisions in the Minister of Petroleum Resources. The Minister carries out these responsibilities through the DPR.

As part of the enforcement mechanism, the Minister may revoke any oil prospecting licence or oil mining lease for several reasons, including failure of the operator to conduct operations continuously, in a vigorous and businesslike manner, and in accordance with good oilfield practices. Also, where the operator has failed to comply with any legislative provision or regulation, or is not fullilling its obligations under the special conditions of its licence or lease, the Minister may revoke its lease. The Minister, at his discretion, may invite the licensee or lessee to provide an explanation for non-compliance. If the Minister is satisfied with the explanation, he may ask the operator to rectify the matter complained of within a specified period. ${ }^{212}$ These represent the major specific provisions on enforcement and related actions in the Petroleum Act that are relevant to this article.

In summary, the Nigerian legal framework needs restructuring to meet the oil and gas industry's regulatory needs. This is necessary both for technical reasons, in terms of the enactment and enforcement of oil and gas conservation legislation, and for the administrative framework, especially in terms of a legislative overhaul and empowerment of the DPR. The role of the NNPC also needs to be redefined to establish it as a commercialized entity that carries out its activities in the public interest of Nigerians. Most of these reforms and their effectiveness will depend largely on the political will of the Nigerian government and its ability to enforce the enacted statutes and regulations.

:11 Funso Kupolokun. "Nigeria Expands Global LNG Market with Train Six" (Paper presented at the Signing of the Final Investment Decision Agreement on Train 6 by Nigerian Liquefied Natural Gas Limited (NLNG) Stakeholders. London, England, 30 July 2004), cited in The Vanguard New:spuper (Nig.) (10 August 2004), online: Nigerian Muse <www.nigerianmuse.com/projects/Chemindustry Project? $\mathrm{u}=$ Kupolokunongas.htm>.

212 Petroleum Act, supra note 85, Schedule 1, paras. 24-27. 


\section{SYNTHESIS AND SUGGESTIONS FOR TRANSFER}

The preceding discussion has outlined the regulatory mechanisms for gas flaring reduction in Alberta and Nigeria. The information gathered in this survey of the regulatory climates of these jurisdictions provides some material upon which to build a legal transplant analysis. In this Part, I analyze the transferability of Alberta's framework for gas flaring reduction to Nigeria based on the propositions of the schools of thought on legal transplant theory. I also draw on the discussions of the regulatory frameworks and background issues in the two jurisdictions in my analysis. In the first section of this Part. I revisit the insights of legal transplant scholars on legal transferability and lean in favour of the view that recognizes the interconnectedness of law and society in legal transplants. A statement of the differences in Alberta and Nigeria in relation to gas flaring regulation follows, and the final section offers suggestions on transferable concepts and principles.

\section{A. Legal, Transplant Theories Revisited}

Professor Alan Watson's views and those of the other two schools of thought on legal transplant theory were summarized earlier in Part II. Watson's theory is premised on the historical contributions of legal transplants to legal change, and from this he derives his autonomy of law argunents. While his historical data is not disputed, the effects of external factors on legal transplants cannot be ignored, for law is not as autonomous as Watson claims. Watson endorses the transplant of ideas and legal concepts, which could be a less contentious approach to legal transplants, though certain ideas could be just as inimical to the recipient state as specific legislation. Where ideas and legal concepts are borrowed, it is possible for the recipient jurisdiction to remodel and redefine them to suit its purposes if this is feasible. On gas flaring reduction, the transfer of conservation principles, the concept of the administrative agency, and ideas of this order (which are not entirely foreign to the Nigerian oil and gas industry, but only need to be accentuated), seem to be a viable venture, of course with accompanying necessary modifications.

The second group of legal transplant theorists, dominated by legal sociologists and proponents of the mirtor theory of law, contend that there is a necessary, systematic connection between law and society. The fundamental question here is how far do the mechanisms set up for gas flaring regulation in Alberta reflect differences between the two jurisdictions. The third group of theorists propose that legal transplants are a virtual impossibility because "meaning" cannot be transplanted across jurisdictions. ${ }^{213}$ Professor Legrand's insistence that one cannot comprehend people as they do themselves is tantamount to saying that "the spirit of a people" cannot be transferred. At one level, this is obviously true. The reception of English laws in Nigeria, for example, has not made the Nigerian legal system the English legal system, but it has certainly modified Nigerian law. Similarly, a transfer of some Alberta oil and gas regulatory concepts to Nigeria would not make the latter an Alberta oil and gas system. At best, several relevant concepts could be modified to suit the Nigerian context and situation. 
I have not attempted to formulate any "grand transplant theory,"214 neither do I construe legal transplants in a broad sense applicable to law and legal institutions generally. This is in recognition of significant differences between jurisdictions and their effect on the reception of legal transfers on the one hand, and the effect of transplanted law on the recipient jurisdiction on the other. The approach taken in this article is eclectic; it borrows and synthesizes ideas from the three schools of thought for the purpose of analyzing the viability of transferring Alberta's gas flaring reduction mechanism to Nigeria. The three schools of thought consider the same idea from different viewpoints and their theoretical arguments turn on their interpretation of the term "legal transplant." The possibility of legal transplants may depend on the meaning one attaches to the term in particular contexts. For the purpose of this article, an exact transplant is not intended. To borrow Professor KahnFreund's terms, neither "organic" nor "mechanical" transplants in the literal sense are the goal as they only serve as metaphors for the effects of legal transplants. The analysis in this article recognizes the necessary connection between law and society and maintains that law cannot be divorced from the socio-political and economic realities of any given society. Notwithstanding the attachment to the point made by legal sociologists on legal transplants, I also borrow from Professor Watson's insights on the transferability of (gas flaring reduction) ideas and concepts, albeit with an extreme cautionary note on the difficulty of transferring ideas generally, for more often than not, it is exactly these ideas and concepts that are contested. At the risk of repetition, this article's focus on legal transferability is restricted to gas flaring reduction mechanisms, in recognition of the limitations of legal transfers.

Going by the extreme view of legal transplants adopted by the third school described in Part II of this article, if Nigeria needs to comprehend the Alberta system as Alberta comprehends it, then a legal transplant may not be feasible. However, if certain viable concepts are adopted and given meanings modified to suit the Nigerian condition, a transfer might be possible. The point is that where acceptable concepts are transferred, several modilications might be accommodated so long as they are not substantial enough to completely change the concept and transform it entirely. Thus, Nigeria might incorporate conservation principles into its oil and gas regulations, but it might not necessarily incorporate the economic elements included in Alberta's definition of conservation. The methods of conservation might also vary slightly because of the differences in geology and land ownership patterns. The diflerences that need to be considered for a meaningful transplant are outlined next, and are based on carlier discussions in this article.

\section{B. OUTLINEd DifFERENCES}

Because countries that developed earlier responses to problems developed them to suit their peculiar needs and circumstances, what might seem to be similar problems in two jurisdictions may require different responses. As a result, a wholesale legal transplant might not be a very effective means of dealing with similar problems elsewhere, even though it might appear efficient. From the discussion of Nigeria and Alberta's regulatory and institutional mechanisms for reducing gas flaring, several differences arise that could affect 
a complete transfer of the Alberta system. Professor Watson opines that the "spirit of the people" can be identified, not from the overall system, but from the details by which it diverges from other systems. ${ }^{213}$ Hence, because no two systems are exactly the same, distinctions need to be appreciated and their possible implications for a legal transplant noted. Some of these differences between Alberta and Nigeria are as follows.

First, Alberta's oil and gas industry is over a century old and gas flaring regulations date back to the early 1930s Nigeria has produced oil and gas in commercial quantities for just about half a century with no significant gas flaring reduction regulation apart from the $A G R A,{ }^{216}$ which has encountered only limited success. Nigeria's oil and gas laws do not emphasize conservation, while in Alberta, conservation has been the centerpiece of oil and gas legislation since the 1930s.

Second, the social and political values of Alberta and Nigeria are based on different ideologies. Alberta has been able to achieve some level of environmental democracy, which is a reflection of a broader political climate that Nigeria does not share. Specifically, the distribution of power within the oil and gas systems of both jurisdictions is substantially different. In Alberta, the Ministry of Energy makes decisions on oil and gas tenure, while the AEUB - an independent regulatory agency - regulates production. However, in Nigeria, decision-making power is concentrated in the Ministry of Petroleum Resources. The Ministry makes decisions on oil and gas tenure and a department of the Ministry - the DPR - also regulates production. The Minister in charge of the Ministry is also the de facto head of the NNPC, which is a major oil and gas producer. For most of the history of oil and gas production in Nigeria, the regulatory body was an arm of the NNPC, which is itself a producer of oil and gas. ${ }^{217}$ These intersections blurred and continue to blur the functions of these establishments, deprive the DPR of institutional independence, and affect the government's regulatory capacity.

Third, revenue from oil and gas is the mainstay of the developing Nigerian economy. Alberta is also dependent on oil and gas for revenue, but to a lesser degree when compared to Nigeria. Consequently, implementing conservation strategies in Nigeria, such as penalizing high GOR wells, might not be as economically and politically feasible as it is in Alberta since most Nigerian oil wells and fields have high GORs because of the high associated gas content.

Fourth, the percentages of associated gas in the jurisdictions differ. About 50 percent of Nigeria's natural gas is associated, while in Alberta the figure is only 20 percent. This translates to Nigeria haying to put in about two and a half times the effort of Alberta to achieve the same level of results in gas flaring reduction.

Fifth, the level of economic development in Nigeria and Alberta's oil and gas industries also differs. The absence of sufficient and ready natural gas markets and related infrastructure is a major factor driving gas flaring in Nigeria. Nigeria does not have the 
advantage of a large continental natural gas market, while Alberta has the nearby American market for its gas and an extensive pipeline infrastructure. Alberta also produces about 80 percent of the natural gas consumed in Canada. Domestic consumption of natural gas in Nigeria is minimal because at the present level of industrialization, large volumes of gas are not required for manufacturing and production.

Sixth, the ownership of oil and gas in the jurisdictions has and continues to differ. Most of Alberta's regulatory mechanisms were developed at a time when most of the oil and gas activity and gas flaring occurred on private land. At this time, the government was not acting both as proprietor and regulator and this could have aided the government's ability to develop effective regulatory mechanisms. In the case of Nigeria, the government has always been both proprietor and regulator.

Seventh, the role of the NNPC in Nigeria makes the Albertan and Nigerian industries substantially different. Alberta has no government-owned oil and gas company that is engaged in oil and gas production. ${ }^{21 x}$ Even though the oil companies are designated operators of Nigeria's JVs, any regulation of gas flaring in Nigeria would, in one way or another, essentially be a regulation of the NNPC, which is a commercialized government entity.

Eighth, a wide variety of oil and gas arrangements are a major feature of the Nigerian oil and gas industry, but this is not so in Alberta. It is possible that the contractual terms of these arrangements impose limits on the government's regulatory capacity. For example, the NLNG Decree, which enacts some of the provisions of the NLNG contract into legislation, contains stabilization clauses. ${ }^{219}$ By virtue of these stabilization clauses, some legislative amendments may amount to breach of contract on the part of the Nigerian government. Other oil and gas contracts may well contain similar clauses.

The foregoing account identifies the major differences between the Albertan and Nigerian oil and gas industries that could preclude a complete transfer of Alberta's gas flaring reduction mechanism to Nigeria. Notwithstanding these differences, the next section considers some viable principles and concepts for gas flaring reduction in Alberta that could be adopted in Nigeria (where necessary and appropriate) with some modification.

\section{Transferable. Conce.pts and Principl.es}

For the purpose of this article, a legal transplant does not necessarily imply a complete transfer of legal rules or systems. Rather, a legal transplant is deemed to occur when one jurisdiction borrows adoptable concepts from another jurisdiction that has developed solutions to problems currently plaguing the recipient jurisdiction. I suggested earlier that the transferability of acceptable general concepts is a more modest endeavour since concepts and principles can be modified to suit the purposes and needs of the recipient jurisdiction, provided they are not inimical and will generate positive results. Where concepts are

21x Alberta used us own the Alberta Finergy Company (AlEC). The Government gradually reduced its ownership untił 1093 when it sold its remaining shares. $A$ merger of AEC with PanCanadian Energy Corporation in 2002 established lincana.

I4 NING Decrec, stupra nole 210, paras. 1, 6, sch. 2. 
transferred, the recipient jurisdiction has the opportunity to remodel and make them reflect its own "spirit and common consciousness." While some might argue that these divergences in the systems create a hew body of laws and cannot be deemed to be a legal transplant, at least the recipient jurisdiction would have learnt something from the donor with which to reform its own system.

This section identifies the general components of the various concepts adopted in Alberta, which could be employed in Nigeria as regulatory mechanisms for gas flaring reduction. I do not engage in a discussion of specific regulatory provisions, such as exact GOR limits, as that would be contrary to the view that I take on legal transplants. Instead, I focus on general and broad concepts and merge both previous and current regulatory approaches adopted in Alberta, to the extent that they might be applicable to Nigeria. At the end of this endeavour, one might not be able to state conveniently that Alberta's gas flaring reduction framework is being transferred to Nigeria. It might be more appropriate to conclude that much of this entails borrowing some ideas on gas flaring regulation and learning strategies from a province that has had the same problems and has developed various means of responding to those prablems.

A first key concept is the general principles of oil and gas conservation and prevention of waste. Conservation is a widespread natural resource management principle, but the interpretation and meaning given to it in various jurisdictions differs, ranging from preservation for future use to the prevention of waste. It might not be feasible to adopt Alberta's interpretation of waste as "economically avoidable waste" at this stage of development in Nigeria's oil and gas industry. Since Nigeria is a developing economy that is dependent on oil and gas production for growth, adopting the "economically avoidable waste" definition in Nigeria might stifle conservation and neglect the environmental, geological, health, and social impacts of gas flaring and the interests of future generations, while ignoring the fact that the economy is only a part of a larger ecosystem and cannot grow beyond the ecosystem. ${ }^{220}$ However, because it is usually not feasible to eliminate all economic considerations, the government could require a balanced weighing of all factors, including economics, when the industry and regulatory mechanisms are mature enough to apply economic principles responsibly. At no point, however, should economic considerations trump any other relevant factor - especially environmental protection. Also, those general economic rationales for condoning pollution from oil and gas production usually paradoxically result in loss of revenue for the local population. This is because the pollution affects local farms and rivers, thereby precluding the local population's access to its major means of livelihood. In addition, it is important to recall that flaring depletes reservoir energy and amounts to economic loss in the long run even though it might seem to make economic sense in the short term.

Second, Nigeria could adopt several oil and gas conservation methods relevant to gas flaring reduction. GC Orders could serve as a means of effecting conservation in several 
fields. MRL and GOR penalties could be adopted in Nigeria in addition to associated gas reinjection. Wells with a very high GOR could be shut in until economic outlets for utilization and conservation are found for the gas. However, where a large emphasis is placed on revenue that could be generated from oil production in the short term, instead of on sustainable development, MRLs and GORs might end up being as unsuccessful as the orders for re-injection made under the $A G R A$, largely because of Nigeria's high associated gas content. GC Orders, MRLs, and GORs could be eflective where all other factors in gas flaring decision making are taken into account in a balanced manner and without a huge bias in favour of petro-dollars.

Third, Nigeria could adopt the general principles of administrative agency regulation instead of the prevailing system where the primary regulator, the DPR, is a department of the MPR. Essentially, the suggestion is for a legislative enactment granting the DPR autonomy and enabling it with the power to regulate the oil and gas industry in the public interest. This method of regulation is not entirely foreign to Nigeria's oil and gas industry. ${ }^{221}$ Its utility lies in its potential contribution to expertise in regulating oil and gas activities and a clear separation between governmenl's responsibilities as proprictor and as regulator. However, in order to incorporale the ideal of independence into administrative regulation in Nigeria, the factors necessary to ensure independence must be present and seen to be present. Also, competent professional staft should be hired and adequately remunerated to carry out and monitor the day-to-day regulation of the industry.

Fourth, the public participation and consultation component of Alberta's oil and gas industry is worth adopting. It is appreciated that this might prove problematic at the outset because, if present at all, principles of environmental democracy are still in very carly stages in Nigeria. However, this could be cultivated just as the governmental democratic institutions in the country are being gradually developed. Public participation will give the citizens, especially the residents of the Niger Delta that are proximate to the flares and other interested parties, the opportunity to contest the activities of the government and oil companies under appropriate legal machinery. Many flares roar just behind the homes of people in the Niger Delta. If these individuals were given the opportunity and the resources to contest applications for well licences, many of the grievances of the communities might be settled.

Several lactors could impede the effectiveness of public participation in Nigeria. First would be the nature of the oil and gas tenure and contracts in Nigeria, which exclude public participation in the manner they are currently constructed. Notwithstanding this, based on the regulatory requirement to notify the regulators of the intention to drill a well, separate from requirements in concessions and contracts, the regulators are in a position to impose adequate regulatory measures on the operation of individual wells instead of lumping wells together under single contracts or OMLs. Second, a significant number of the residents of

$\because:$ For cxample. Ihere is the linergy Commission of Nigeria created by the Energy Commission of Nigeria Act, (I.F.N. $194(0)$ \&. 109 and the Oil and Gas Export Free Zone Authority (see supro note 209). There are also constilutionally cstablished commissions, including the Federal Civil Service Commission, the Federal Character Commission, and the Independent National Electoral Commission. See s. I53 ol the 1999 Constimuion, supra note 84. 
the Niger Dejta are illiterate and might not adequatcly comprehend the nature of public participation proceedings.

Despite these limitations, many contentious issues and hearings may be avoided if the government enacts and enforces regulation to ensure that industry engages in adequate consultation with all concerned parties. Government must ensure that consultation does not descend to endless unproductive dialogue. Apart from hearings by the regulatory agency, the government should provide mechanisms for judicial review of the decisions. If judicial review of the regulator's decision were available and effective, it could mitigate much of the social unrest and disturbance in the Niger Delta.

Fifth, the Alberta multi-stakeholder approach to oil and gas development is a concept that should be emulated in Nigeria. Stakeholder involvement in formulating regulations creates a sense of shared responsibility for compliance. It provides a forum for discussion between industry, government, non-governmental organizations (NGOs) (including environmental groups), citizens, and other interested parties to negotiate issues and reach a workable compromise. Such co-operation between all stakeholders in Nigeria would provide an opportunity to formulate regulations that parties comply with, rather than just a set of regulatory requirements that exist only on paper. However, this point, like most of the others, might encounter problems within the Nigerian context. With regards to the transnational oil and gas companies and the Nigerian government, the argument again turns on revenue generation. Where the government places significant emphasis on revenue from oil and gas production over and above other considerations, multi-stakeholder consultations might yield results that remain unfavourable to the country's overall welfare. However, the presence of NGOs and other interested parties might encourage a balanced decision-making process as opposed to a revenue-generation-driven approach. For the purpose of clarity, the suggestion is not that revenue generated from oil and gas production is unnecessary. Rather, it is that a more balanced approach to the advantages and detriments of oil and gas exploitation is required in order to make the most of the resources.

Sixth, even if the proliferation of government departments involved in oil and gas production and the resultant overlapping and conflicting of jurisdiction in Nigeria persists. the adoption of the one-window approach to regulation employed in Alberta would serve as a means of reducing the duplication of functions. It might also aid the government in realizing that it does not require multiple departments to carry out functions that fewer institutions could effectively handle. It would save administrative costs, reduce burcaucratic delays, and avoid the unnecessary duplication of functions. It would also encourage the development of expertise in certain government departments or agencies responsible for specific functions and promote accountability.

Seventh, governments all over the world claim to carry out acts in the interest of the public. Including a public interest mandate in Nigeria's oil and gas legislation could serve as a basis for holding the government accountable for effective regulatory mechanisms and gas flaring reductions in Nigeria. As in Alberta, decision makers should consider environmental, econonic, social, and technical factors when contemplating decisions on gas flaring. 
Eighth, an objective hierarchy on gas flaring management and a flare management decision tree, similar to that in Alberta's Directive 060, ${ }^{222}$ would provide a framework within which regulators could make gas flaring decisions in Nigeria. The objective hierarchy and decision tree would require elimination of flares where feasible. Realistically, in Nigeria, the elimination of gas flaring would require financial resources, commitment to the task, and some time to substantiate. This makes the next step on the hierarchy - substantial reduction of the amount of flared gas - an important one at this initial point in gas flaring regulation. Where flaring cannot be avoided, such as emergencies, the law might prescribe that gas flaring must only occur according to efficient flare performance requirements based on the best available technology standard and that emissions must be subject to the regulatory control of the FEPA.

Ninth, without comprehensive enforcement procedures, law reform may be a waste of time and totally ineffective. Presently, Nigeria has a system of comprehensive financial incentives but little or no enforcement mechanisms in place for gas flaring reductions or any other oil and gas operations for that matter. Voluntary approaches have not been successful to date in Nigeria. Although this has not been the case in Alberta, oil and gas operators in Nigeria have proven that if left unregulated they would not conduct any satisfactory self-regulation but, rather, only operate a profit-driven industry mostly beneficial to the companies. As a result, a voluntary approach to industry regulation is not a method to adopt at this time in the country's history of regulating oil and gas exploitation. However, enforcement mechanisms should not be unrealistic ${ }^{233}$ and a system of graduated levels of non-compliance, with appropriate consequences thereto, could be adopled.

To ensure effective monitoring of oil and gas production and gas flaring in Nigeria, applications for well licences should be a strictly-enforced compulsory requirement irrespective of the nature of the operators' tenure. The regulatory agency should post competent professional staff to field stations in oil-producing areas in order to monitor the activities of the operators. Operators should be required to publish monthly information on the amount of gas flared from operations, the amount conserved and utilized, and the efficiency of combustion methods applied. The regulators should, in turn, publish annual reports on gas flaring and conservation performance in the country. Publication of this information would enable industry and regulators to appreciate the amount of effort put into gas flaring reduction, and the amount of work needed for further reductions. It will also aid in meeting reduction targets and help formulate further realistic goals.

Tenth, Nigeria needs a comprehensive document on gas flaring reduction regulation similar to Alberta's Directive 060, which would be dralted after consultation with all stakeholders. Current Nigerian oil and gas statutes and regulations were drafted primarily to regulate oil production, and no legislation, except the $A G R A$ and a few provisions in the Petroletm Regulations, regulate gas flaring. The purpose of drafting a comprehensive document like Directive 060 is not to copy the provisions of Directive 060 and dump them on the Nigerian oil and gas industry. Nor is it to require the same flared gas reduction targets within similar periods. The idea is that since gas flaring has attained epidemic proportions

23 lior example. the AGRA's provision for revocation or OMLs has never been invoked but the provision remains in Nigeria's statute books. See AGRA, supra note 188, s. 4(1). 
in Nigeria, legislators and regulators should as much as is practicable. incorporate all regulatory requirements for the reduction and eventual elimination of the practice in a single document for clarity and ease of reference.

\section{Conci.usion}

Alberta's gas flaring reduction framework gradually developed over the years to its present level of regulatory sophistication and competence. The leaders of the regulatory agencies and the provincial government were willing to allocate the necessary resources to effect the conservation of natural gas. Similarly, a lot of work from every concerned sector will be required to effect any required changes in the Nigerian gas flaring regulatory system and ensure their implementation. A lot of the decision making depends on the government, its policy formulation, and political will to carry out reforms in the oil and gas industry. The governmental structures in charge of, and the policies relating to, oil and gas exploration and production require substantial overhauling before any meaningful regulatory mechanisms can be put in place to reduce gas flaring in the country. Regulatory incompetence is a problem that largely pervades many legal systems generally and is not peculiar to regulation of the oil and gas industry. As a result, achieving any meaningful legislative and regulatory success in the Nigerian oil and gas industry might involve a wider restructuring of the ideals that shape the country's legal system generally.

History and recent events show that there is a wide gap between rhetoric and reality in the Nigerian oil and gas industry. In spite of the propaganda about sustainable development and total gas flare out by the Nigerian government and industry, the gas flares in the Niger Delta still roar 24 hours a day, seven days a weck. They even occur in residential areas. Rather than rely on propaganda of corporate social responsibility at the expense of environmental protection, health and safety, and other relevant considerations in oil and gas production, all stakeholders should return to the drawing board to seek out appropriate ways to stop gas flaring or substantially reduce the activity. Stakeholders appreciate that a lot of resources will be required to achieve any substantial reduction of gas flaring in Nigeria, but this is not enough reason for government or industry to backpedal on their flare out targets, as they did in May 2005. ${ }^{234}$ Financial incentives granted by the government are a good step towards encouraging significant reduction in gas flaring; and government and industry need to seck out more utilization opportunities that make long-term cconomic sense, as the monetization of conserved gas will contribute more to the development of the country than flaring has.

The ten points I have outlined above reflect the transferable concepts and practices from Alberta to Nigeria on gas flaring reduction, with the necessary modifications and anticipated problems. For those issues on which it is not feasible to adopt Alberta practice, the Nigerian government has to formulate policies that suit the country. Irrespective of the policies that

$:: 4$ In reaction to statements by Shell Nigeria and the Nigerian government that gas flaring will not stop by the 2008 llare out targel, a Niger Delta community, with the support of Ensironmental Rights Action (Friends of the larth Nigeria) filed a suit in the Federal High Court. Benin. Nigeria. on 20 Junc 2005. to compel the companies to shut-in wells where there are no utilization facilities in place. The Court rendered its decision in the suit - Gbemre, supro note 200 - against the defendants linding that they were in violation of human rights and found the provisions of the AGRA 1990, supra note 188 , allowing continued flaring subject to the payment of fines, inconsistent with the constitutionally guaranteed right to life. 
the government decides to formulate, it has to make a decision to ensure that the goal is real development and not just short term economic growth. Concrete gas flaring reduction decision making needs to be carried out and implemented to ensure that the waste of a valuable non-renewable resource and the continuing environmental degradation stop. The Nigerian people, future generations and certainly, the ecosystem, deserve no less. 